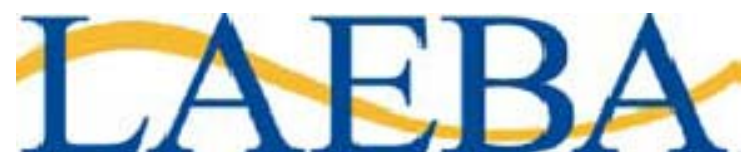

Latin America/Caribbean and Asia/Pacific

Economics and Business Association

An initiative of the Inter-American Development Bank and the Asian Development Bank Institute

First LAEBA Annual Meeting

Beijing, China - December 3-4, 2004

\title{
Fear of China: Is there a future for manufacturing in Latin America?
}

Mauricio Mesquita Moreira - IDB

Sponsored by

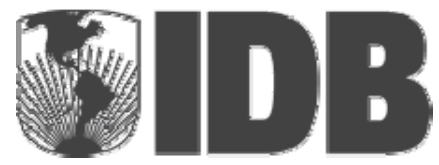

Inter-American Development Bank Integration and Trade Sector

Institute for the Integration of Latin American and the Caribbean (INTAL)

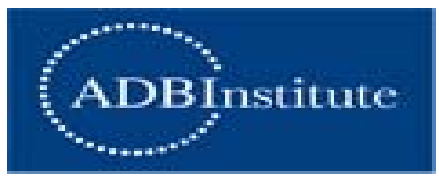




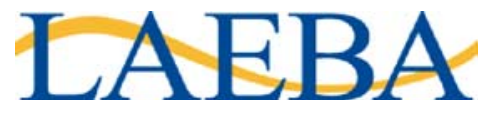

Latin America/Caribbean and Asia/Pacific

Economics and Business Association

An initiative of the Inter-American Development Bank and Asian Development Bank Partnership Agreement

WORKING PAPER No.33

December 2004

\section{Fear of China: Is there a future for manufacturing in Latin America?}

By Mauricio Mesquita Moreira, Inter-American Development Bank

PRESENTED AT THE 2004 LAEBA ANNUAL CONFERENCE, BEIJING, PEOPLE'S REPUBLIC OF CHINA • DECEMBER 3-4, 2004

Sponsored by:

Inter-American Development Bank Integration and Regional Programs Department

The Japan Program

Institute for the Integration of Latin

America and the Caribbean (INTAL)

Asian Development Bank ADB Institute 
WORKING PAPER SERIES No.33

December 2004

Fear of China: Is there a future for manufacturing in Latin America?

Mauricio Mesquita Moreira, Inter-American Development Bank 


\section{LAEBA OVERVIEW}

The Inter-American Development Bank (IADB), through the Integration and Regional Programs Department, and the Asian Development Bank (ADB), through the ADB Institute jointly coordinate the "Latin America/Caribbean and Asia/Pacific Economics and Business Association (LAEBA)." LAEBA is dedicated to advancing economic linkages between the two regions through cross-regional and comparative research and exchange.

The LAEBA initiative results from an inter-agency Partnership Agreement signed on March 17th, 2001 between the IADB and ADB at the 42nd Annual Meetings of the Board of Governors of the IADB and the Inter-American Investment Corporation (IIC) in Santiago, Chile. The Partnership Agreement promotes the exchange of knowledge, experiences, and expertise to support regional development assistance.

The mission of LAEBA is to:

- Encourage comparative and applied research in the areas of economics, finance, business economics, and public policy of both regions.

- Provide an inter-regional framework for professional networks to collaborate on issues of mutual interest between the regions.

- Facilitate and inform the process of economic policy-making and private sector decisions through enhanced interaction among policymakers, academia, and the business community.

\section{WWW.LAEBA.ORG}

These publications are also available online at http://www.laeba.org.

Copyright $\odot 2004$ Inter-American Development Bank and the Author. All rights reserved. Produced under the LAEBA IADB-ADB Partnership Agreement.

Edited by the Integration and Regional Programs Department (INT) of the IADB

The Working Paper Series is sponsored by LAEBA, an initiative of the IADB-ADB (Inter-American Development Bank - Asian Development Bank) Partnership Agreement. The Series primarily disseminates selected work in progress to facilitate an exchange of ideas within LAEBA and the wider academic and policymaking communities. The opinions expressed herein are solely those of the author/s and do not necessarily reflect the position of the sponsoring institutions. Thus, LAEBA and its sponsoring institutions accept no responsibility whatsoever for any consequences of its use. The authors, in the exercise of their academic freedom, choose names of countries or economies mentioned in this series and LAEBA and its institutional sponsors are in no way responsible for such usage. 


\title{
Fear of China: Is there a future for manufacturing in Latin America? ${ }^{1}$
}

\author{
Mauricio Mesquita Moreira \\ Inter-American Development Bank \\ Integration Department \\ October 2004
}

\begin{abstract}
China's emergence has raised pointed questions about the future of manufacturing in Latin America. Once saw as its economic future, the viability of this activity in the region has long been challenged by traditional trade theory and, in practical terms, by at least three generations of Asian Tigers. China and its "unlimited supply of labor", rapid productivity growth, scale, and extremely interventionist state has brought the practical challenge to unprecedented levels. This paper, using mainly descriptive production and trade statistics, looks at the nature of this challenge and its implications. It begins by dealing with a central issue: Does manufacturing still matter for Latin America's development? It argues that even though there are other options that should be exploited, the region cannot afford to completely turn its back to a well-proven road to development. It then moves on to examine the scope and nature of the Chinese challenge. It shows that endowments, productivity, scale and the government role, all work together to make China a formidable competitor. The importance of this challenge is confirmed by an analysis of the trade data, which suggests a small impact so far, but a trend that should make Latin American policy makers uncomfortable in their seats. The paper concludes by discussing, in general terms, the (difficult) policy options available.
\end{abstract}

\section{Introduction}

China's emergence in the world market raises pointed questions about the future of Latin America and the Caribbean (LAC) in the world's division of labor. The once dominant view that the economic future of the region was in manufacturing has long been challenged by traditional trade theory and in practical terms by at least three generations of Asian Tigers (e.g. Japan, Korea, Malaysia). China and its "unlimited supply of labor", rapid productivity growth and extremely

\footnotetext{
${ }^{1}$ Background paper for the IADB Report on China. I am grateful to Robert Devlin, Marcelo de Paiva Abreu, Andrés Rodríguez-Clare, Elio Londero and Jorge Chami Batista for their comments. None of them though should be held responsible for the views expressed here.
} 
interventionist state has brought the practical challenge to unprecedented levels. This paper, using mainly descriptive production and trade statistics, looks at the nature of this challenge and its implications.

It is divided into five sections, including this introduction. It begins by revisiting a time-old question: Does manufacturing really matter for LAC's development? The implications of China's emergence, including the possible responses, depend on the answer given to this question. It then moves on to examine, in section three, what are the challenges posed by China for manufacturers in the region. Is it an endowment or technology type of challenge? What about the competitive implications of "market socialism"? Section four, using correlations and standard shift-flow analysis, looks at past, existing and potential trade impacts on LAC of China's growing presence in the world markets. Does it confirm the severity of the challenge? The last session concludes by discussing, in general terms, the (difficult) options available to policymakers.

\section{Manufacturing?}

What the literature has to say? -- One could reasonably expect that, after more than half a century since Prebisch (1950) published the "The Economic Development of Latin America and its Principal Problems", the issue of whether manufacturing matters would have been settled. Yet, the debate in the region seems to go on fuelled, first, by LAC's poor industrial performance and second by the fact that economists have yet to agree on the relevance of the "natural resource curse".

A couple of papers by Sachs and Warner $(1995,1997)$ seem to have reignited the debate, with results that suggested an inverse relationship between natural resource and growth. They explained their results mainly on the grounds of externalities and increasing returns associated with manufacturing. Even though the empirical results were new, the authors were revisiting an old controversy 
about the links between industrialization and growth. This controversy was never satisfactorily resolved--mostly because of the difficulties in empirically identifying the channels through which industry promotes growth--yet policy makers and most academics have long behaved as if the issue had already been settled.

Developing countries have been pursing explicitly and implicitly industrialization since at least the 1950s, first with import substitution, led by Latin America and then through export promotion, led by East Asia. In the academia, development has been usually equated with industrialization, and the notion that there is a "normal" pattern of development (see e.g. Chenery, Robinson and Syrquin 1986 and Rowthorn and Ramaswamy 1997) that goes from agriculture to manufacturing and then services, is still today a deep-seated, although not always explicit, belief in the profession. Not so long ago, some went as far as declaring the existence of a "manufacturing consensus", which would exist beyond policy issues: "The main issue between the proponents of neoclassical trade policy and its critics is not whether to industrialize but what form industrialization should take." (Chenery, Robinson and Syrquin 1986, p. 4 quoting Krueger 1984).

Evidences of this "consensus" are widespread. For instance, developed countries are usually referred to as "advanced industrial economies" (e.g. Grossmann and Helpman 1994:33) and the notion that manufacturing is the cradle of innovation and, therefore, the handmaiden of growth, is very much present in the "new" theories of endogenous growth. These theories typically speak of "industrial innovations" and of learning-by-doing happening mainly in manufacturing (e.g. Aghion and Howitt 1992 and Grossman and Helpman op.cit). Contemporary development literature also seems to suggest that industrialization is still the way to go, working with models where there are traditional and modern sectors 
and speaking of "[...] fostering industrial growth and transformation" (Hausman and Rodrik 2002, p. 17.).

Murphy, Shleifer and Vishny (1989), in a well known paper, give perhaps the best evidence of, and justification for, the profession's manufacturing bias. They argue "virtually every country that experienced rapid growth of productivity and living standards over the last 200 years has done so by industrializing. Countries that have successful industrialized--turned to production of manufacturing taking advantages of scale economies--are the ones that grew rich, be they eighteen century Britain or twenty century Korea and Japan."(p. 1003). One could easily add China to this list, but this is the subject of the next section. ${ }^{2}$

Sachs and Warner's results, though, did not settle the issue. Their paper has been followed by a number of studies challenging or supporting their findings. Lederman and Maloney (2003), for instance, present some evidence that what hurts growth might not be specialization in natural resources per se, but high concentration of exports in any item. Manzano and Rigobon's (2001) results, in turn, suggest that in the period analyzed by Sachs and Warner (1971-89) the problem might have been the "debt-overhang" and not specialization in natural resources. None of these studies, though, deals satisfactorily with the fact that natural resource specialization might be behind both concentration and over borrowing. The link to concentration, for instance, is evident in Stijns (2003), whose findings point to a substantial crowding-out of manufacturing by energy exports.

\footnotetext{
2 This is a view that also seems supported by economic historians. As Bradford Delong and Summers (1991: 447) put it: "The history of economic growth is often written as if nations and industries either seized the opportunity to intensify their specialization in manufactures and grew rapidly, or failed to seize such opportunities and stagnated."
} 
Other studies raise the issue of an indirect and negative impact of natural resource specialization on growth. Isham, Woolcock, Pritchett and Busby (2003), for instance, find evidence that export concentration on "point-source" natural resources (defined as those extracted from a narrow geographic or economic base such as oil, mineral and plantation crops) "are strongly associated with weak institutions which are, in turn, strongly associated with weak growth"(p.4). Easterly and Levine (2003) reach similar conclusions. Gylfason (2001) Gylfason and Zoega (2002), in turn, look at other channels and their results point to a negative impact of natural resource rents on investment in physical and human capital, which are key determinants of growth.

The policy debate-- Even though the econometric evidence seems to favor, directly or indirectly, the manufacturing option, the issue is far from settled. This, however, has not prevented the "contagion" of the policy debate, where one can find quite strong policy statements on the appropriate pattern of the LAC's specialization. De Ferranti et al. (2002), for instance, dismiss promanufacturing and resource curse type of arguments, citing Lederman and Maloney (op cit) and relying on the history of successful natural-resource abundant countries such as Canada, Australia, Sweden and Finland. The report urges Latin America not to turn its back on natural resources, seen as pathway to a "knowledge economy".

Blum and Leamer (2004), though, offer a different perspective. They share the De Ferranti et al. (2002) pessimism with regard to the future of manufacturing in the region on the grounds of geography and endowment. As they put it, "LAC is far way, rich in natural endowments and has a tropical climate [...]" (p.569). And "[...] far away resource abundant tropical countries have great difficulties attracting manufacturing activities, other than mundane and labor intensive tasks like sewing hems on t-shirts" (p. 540). But unlike the World Bank, they do not think that this is a blessing: "Natural-resource-rich communities invest their 
resources in land, permanent crops and extractive equipment and very little in human capital, which has a very low return on a coffee plantation or the equivalent. This creates a barrier to development since once the resource is fully developed and further wealth accumulation could only come from growing manufacturing, the educational system may not be ready to prepare the workforce on the factory floor." (p. 547)

They also warn about the difficulties of generating jobs in capital intensive and fixed-input (land), resource-intensive activities: "Countries that cannot attract manufacturing activities face the very difficult problem of how to find work both for new entrants into the labor force and also for the natural-resource workers who are inevitably displaced by mechanization." (p. 546)

Finally, they dismiss the natural resource success stories as "not completely meaningful" to Latin America, inter alia, because countries like Canada, Finland and Sweden "may have made a commitment to broad human capital accumulation for non-economic reasons prior to the period when the private return to human capital exceeded the private return to physical capital" (p.5). Acemoglu, Johnson and Robison (2002) argue that these "non-economic reasons" have to do with the "settler" institutions created by Europeans colonialists in the natural resource poor (at least in the way they were perceived at that time), scarcely populated and environmentally attractive areas of the new world, as opposed to the "extractive" institutions of the tropical, inhospitable and natural resource rich regions of the South.

Even though these contributions are far from exhausting the policy debate, they reflect well the two strands of "manufacturing pessimism" that prevails in academic and policy circles, particularly in the North. They both, however, seem to stand on shaky grounds. The review of the empirical literature made above does not support the natural-resources enthusiasm of the first strand. In fact, the 
evidence seems to confirm the direct or indirect negative impacts on growth of natural-resource specialization. The success cases strike more as exceptions than rule. Apart from the institutional argument discussed above, the transition into manufacturing was a crucial element of their success. They made this transition counting on a human capital base that preceded the natural-resource development and in a global environment where fragmentation of the production processes was still incipient, hampered by transport costs and tariff and non-tariff barriers. In other words, they were in better conditions to explore linkages and diversify into manufacturing.

Sure, Chile of the nineties is a "domestic" natural-resource success. Yet, Chile's success (which, by the way, still has close to 40 percent of its exports linked to one single product-copper) is dwarfed by the growth, diversification and technological sophistication of the "manufacturing" East Asia and is matched by Venezuela's failure, which bears clear symptoms of Dutch Disease. ${ }^{3}$ But, perhaps, even more relevant from a policy point of view is the fact that the bias against natural-resource intensive activities, for the overall majority of countries in the region, is a thing of the ISI past. Trade liberalization and the hands-off policy that prevailed throughout the nineties led these economies to a regime as close to a "neutral" system of incentives as it has ever been. The "don't-turn-your-back" kind of advice does not seem to have, then, any practical consequence.

Likewise, the argument of the second strand that LAC's manufacturing is doomed by geography and endowments seems to overlook both important pieces of theory and facts. The "new" theories of endogenous growth, which, as mentioned above, have manufacturing at their core, emphasize the importance of innovation and learning, which, in turn, depend fundamentally on the accumulation of human capital. That is, they give pride of place to a type of 
endowment that might be influenced by the complex interplay of geography and institutions, but that also respond to policy.

One way of reading these theories is to argue that accumulation of human capital and the ensuing process of learning and innovation can change a country's destiny beyond its geography and natural endowments. History has a number of examples of this happening, but one of the most telling episodes happened in South Korea. After the Korean War, the UN hired specialists to consider South Korea's future economic prospects. The so-called Nathan group based their planning (which fortunately was never implemented) on the assumption that South Korea export prospects and comparative advantage lied in agriculture and minerals! (Krueger 1979, p. 77)

Figure 1 - Manufacturing Value Added (\% of GDP)

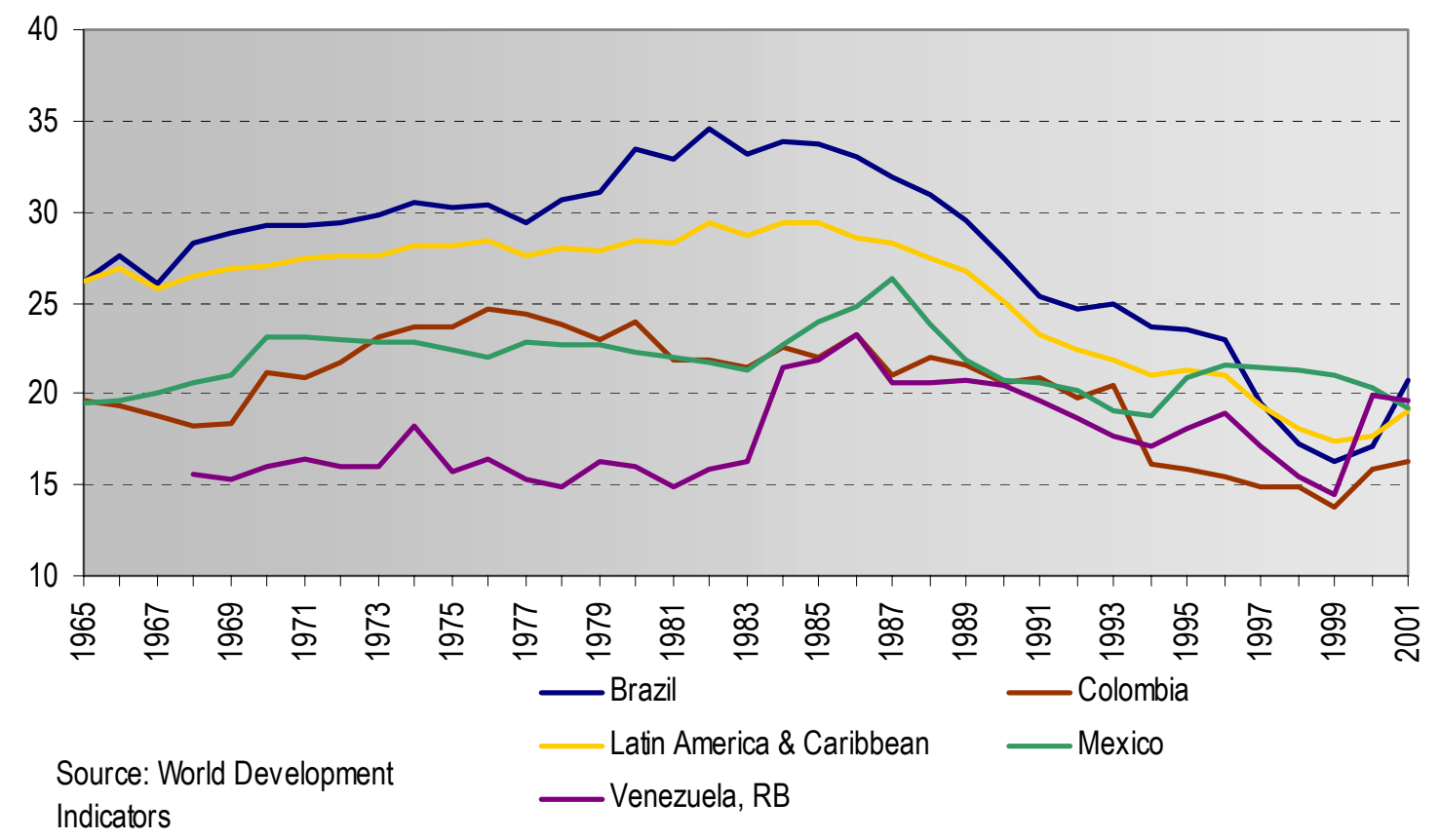

${ }^{3}$ Houseman (2004), however, disputes this view. However, it seems hard to rule out the Dutch Disease hypotheses altogether in a country where oil related exports (SITC 3) account for 80 per cent of total exports (2002 data). 
One cannot also ignore the fact that after more than a decade of trade liberalization, an average of approximately 20 percent of the region's GDP is still produced in the manufacturing sector (see Figure 1) and that countries such as Mexico and Brazil are significant exporters of manufacturing goods. True, the manufacturing share of GDP has been declining rapidly; output and exports of manufactured goods are still dominated by "mundane" resource and labor intensive goods or are concentrated in the labor-intensive links of the value chain; and the region has been having difficulties to increase its limited share of the world market, being thoroughly outperformed by East Asia (see Lall, Albaladejo and Moreira 2004).

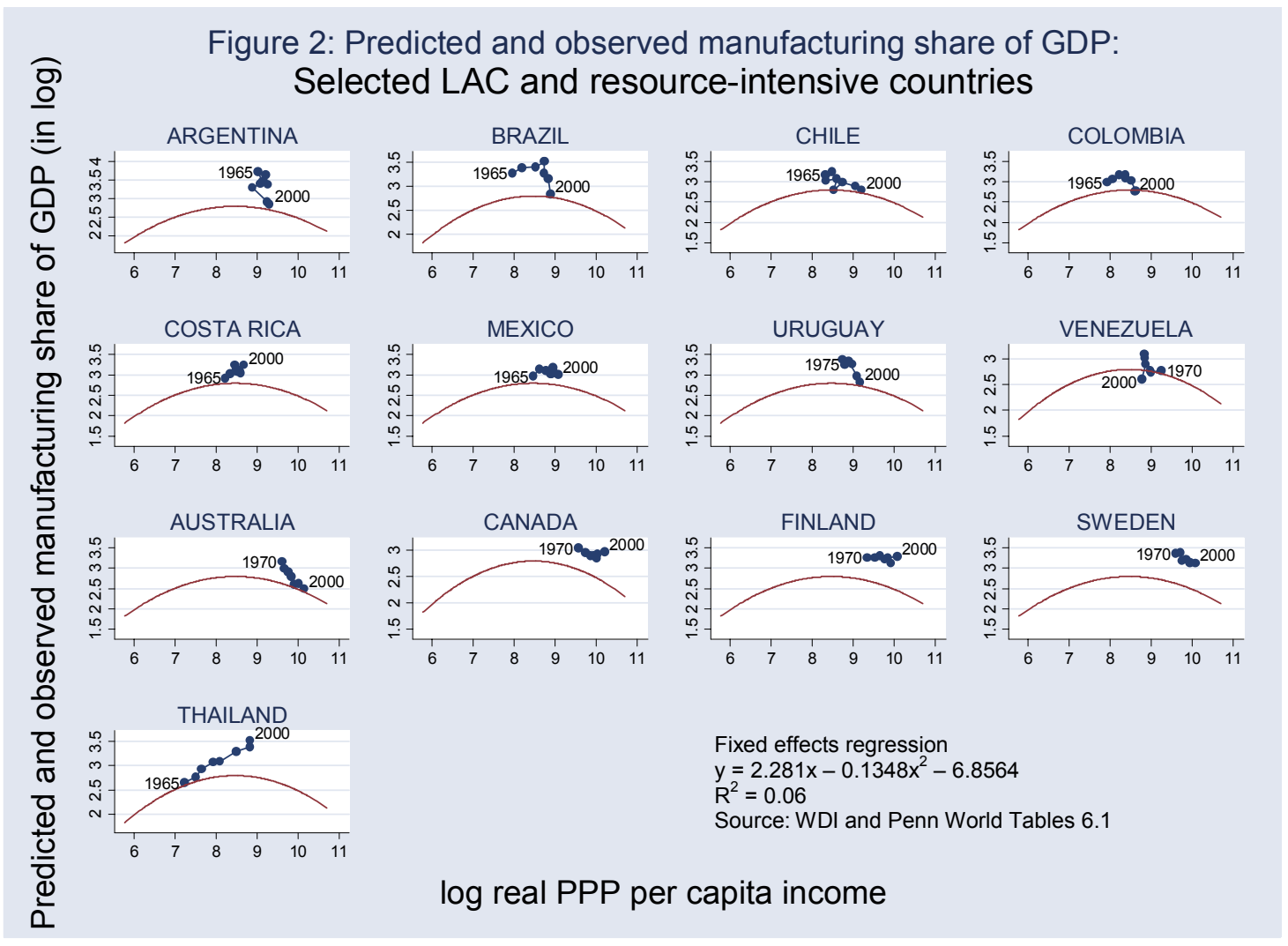

Yet, there seems to be more to LAC's manufacturing tribulations than endowments and geography. The declining share of the GDP can be seen, at least in part, as an inexorable adjustment to the manufacturing overshooting 
produced by import substitution policies (ISP). It might also reflect a fall in the relative price of manufacturing goods vis-à-vis services driven by trade liberalization. As show in Figure 2, most Latin American countries have gone though a drastic process of adjustment to the "norm". ${ }^{4}$ That is, they have achieved in the 60s and the 70s a level of industrialization, measured by the manufacturing share of GDP, higher than predicted by its per capita income. Trade liberalization, mostly in the mid-80s and 90s, seems to have played a part in bringing the observed closer to the predicted levels.

This performance would also be consistent with a region that is living up to its geography and endowments. Yet, the performance of other natural-resource intensive countries such as Canada, Finland, Sweden and Thailand suggest that there might be other factors at play in this convergence. Not only these countries have maintained manufacturing shares systematically higher than predicted, but they also show no strong signs of convergence, despite their open trade regimes. The exception here is Australia, yet its convergence seems to happen at much higher levels of per capita income than in LAC.

The simple exercise shown in Figure 2 could be more meaningful if the "norm" reflected the countries' size and factor endowments. An attempt in this direction is show in Figure 3, which presents a measure of the countries' deviation from the "norm", taking into account their size (population), endowments of physical and human capital, energy and land (see Table A.1 for details). For lack of data, the exercise does not cover the nineties, period where trade liberalization was deepened in the region; yet, it still produces some useful insights. At first sight, the results are consistent with an overshooting and a process of convergence that in the early nineties was close or had already gone even beyond eliminating any

\footnotetext{
${ }^{4}$ There are arguably two factors behind the curvature of the norm: faster productivity growth in manufacturing than in services, which drives down the relative prices of the former and the operation of the Engel's law which leads to a change in the pattern of demand from agriculture to manufacturing and services. See Rowthorn and Ramaswamy 1997,
} 
"fat". However, since, as we have seen in Figure 1, the share of manufacturing in the GDP continued to fall significantly throughout the nineties, it is possible that during this period the region's level of industrialization might have fallen below the "norm". So, convergence and overshooting might not tell the whole story. Moreover, judging by the performance resource-intensive countries such as Thailand, one is also tempted to think that there is more than "destine" behind this deindustrialization.

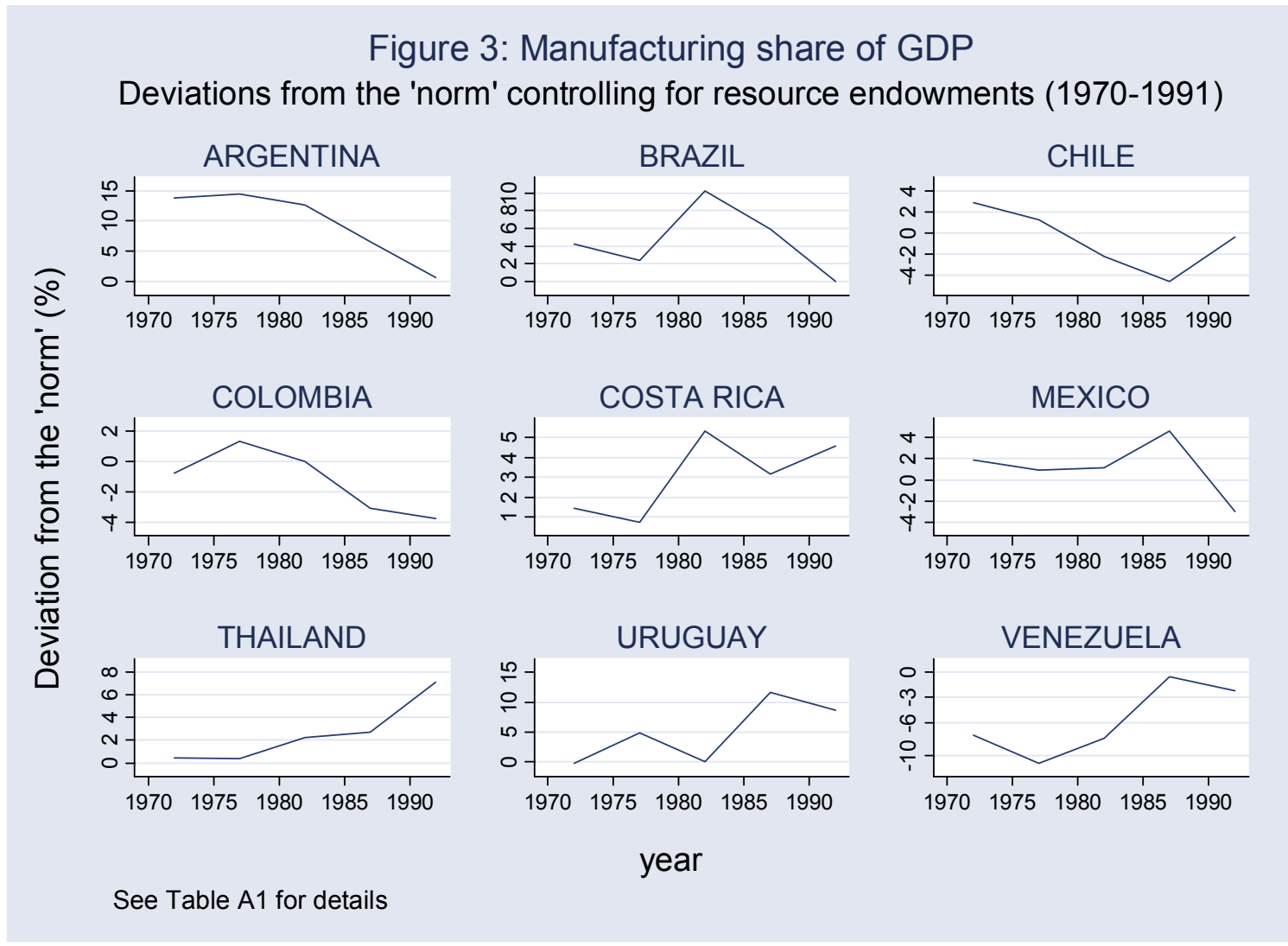

In fact, there are least two important "omitted variables" in this story. The poor and volatile macroeconomic environment that prevailed in most countries in the region throughout the eighties and nineties and a reform of the state which has gone well beyond weeding out the excesses of the import substitution era. The first variable requires little introduction. LAC has a well-known long record of macroeconomic mismanagement and fiscal irresponsibility, and has spent most of the last two decades coming to terms with its troubled past. Important 
progress has been made in this area, but not without costly mistakes, particularly in the choice of exchange rate regimes. Long periods of overvalued exchange rates in countries such as Brazil, Mexico and Argentina have taken a heavy toll on tradables in general and on manufacturing in particular.

The second variable is far from consensual and has to do with the time-old polemic about the government role in the process of industrialization. Most LAC governments--as a reaction to the bloated, inefficient state of the years of import substitution--have leaned towards an agenda that demonized government intervention and, as a result, they have exposed producers in the region to damaging market failures. Economists are generally comfortable with models that incorporate market imperfections driven by externalities, imperfect information and economies of scales and which are particularly relevant for industrial development. Yet, they usually balk at policy solutions mainly on political economy grounds. Clearly, the record of government intervention in LAC has been particularly poor and might justify this attitude. Yet, this poor record has a lot to with a closed trade regime and with the fragility of Latin American institutions. As it is well known, much has changed during the nineties.

In any event, the bottom line is that even a cursory analysis of manufacturing in LAC shows that firms suffer from several disadvantages. For instance, they do not have access to sufficient financing; they lack the incentives to invest in human capital and technology; and more than anything they are up against competitors that can count on generous government assistance in all these areas, particular in East Asia. So the history of LAC manufacturing in the last decades is the history of an industry which had to shrink and adjust to the realities of an open economy and in this process faced unfavorable geography and endowments; but it is also the history of an industry which had to grapple with 
an extremely inhospitable macroenvironment, with a less than supportive government and with competitors heavily supported by their governments.

Against these evidence and arguments, an honest answer to the issue of whether manufacturing matter for LAC development is a qualified yes. It is not a matter of biasing incentives against natural-resource activities. This would mean to go back to the costly distortions of the ISI era. Yet, one cannot ignore the risks involved on a pattern of specialization based on natural resources. The econometric evidence, although inconclusive, does seem to confirm those risks and, at the very least, underlines the advantages of diversification. The theory also seems to give manufacturing a key role in promoting human capital, innovation and growth, irrespective of the countries' geography and endowments. So there seems to be enough grounds to urge LAC not to turn its back on manufacturing, a sector, unlike natural-resources activities, where governments have good reasons to be concerned about market failures and foreign targeting. The emergence of China in the world markets, as discussed in the next section, not only reinforces this point, but also takes the already difficult challenge of developing a strong and competitive manufacturing sector in the region to another frightening level.

\section{The Chinese Challenge}

Why China is a formidable threat for LAC's manufacturers? There are at least four types of challenges.

Endowments--The first is what can be called the endowment or "HeckscherOhlian" challenge. With a population of 1.3 billion and a labor force of 640 million sitting on a limited amount of natural resources, China has a huge comparative advantage in labor-intensive goods. This labor abundance translates into wages that are well below the levels practiced throughout most LAC. Figures 4 and 5 compare, respectively, current and purchase-power-parity (PPP) 
manufacturing wages among China, Brazil and Mexico. The figures for nominal wages are heavily driven by movements in the exchange rate: i.e. Brazil's mega devaluations after 1999 and the appreciation of the Mexican peso after the 1995 crisis. Yet, as it can be seen, even at its most favorable year, Brazil's wages topped China's by a factor 3 (2002) and in the case of Mexico by a factor of 5 (1998).

Figure 4- Average Nominal Annual Wages in Manufacturing: China, Brazil and Mexico (1000 current US\$)

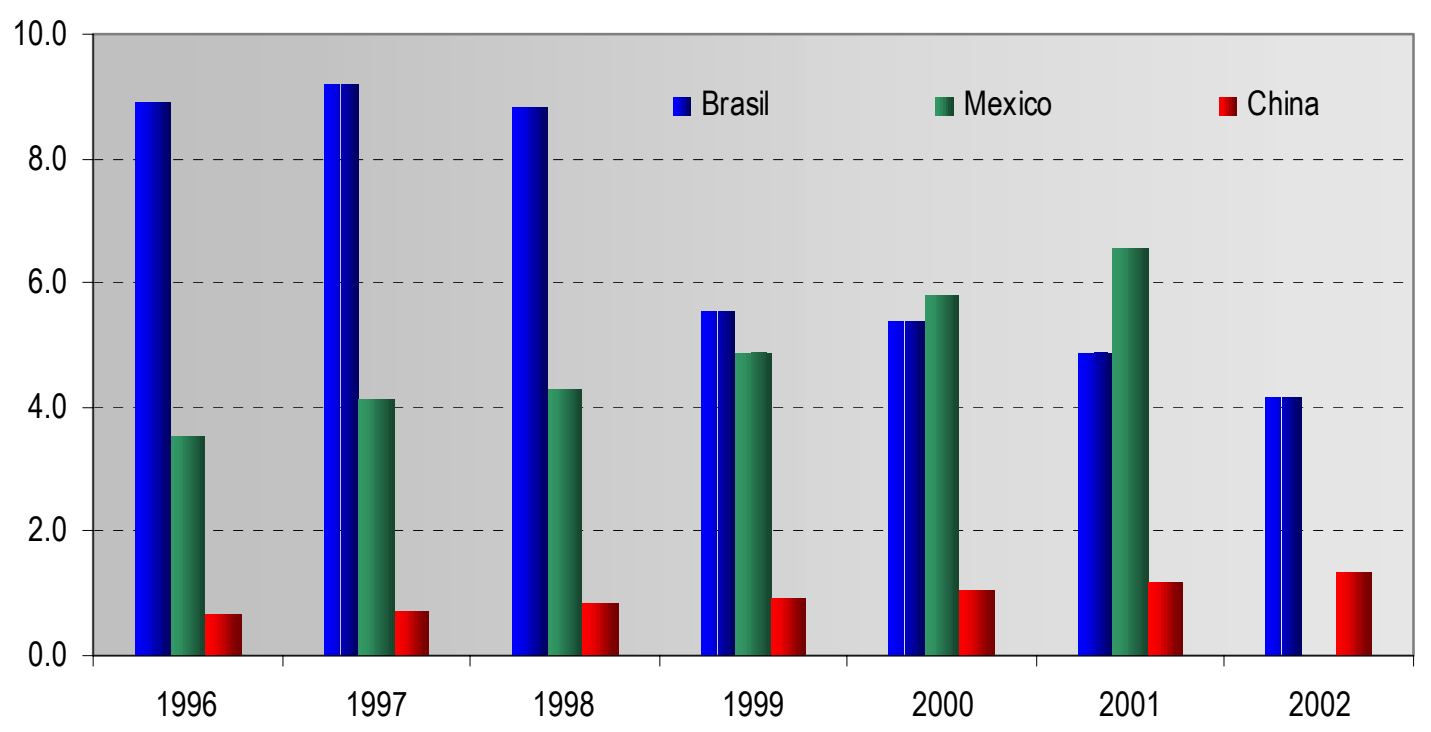

Source: China Statistical Yearbook, IBGE and INEGI annual industrial surveys 
Figure 5: Manufacturing Wage Gap: Brazil, Mexico versus China

( PPP US\$)

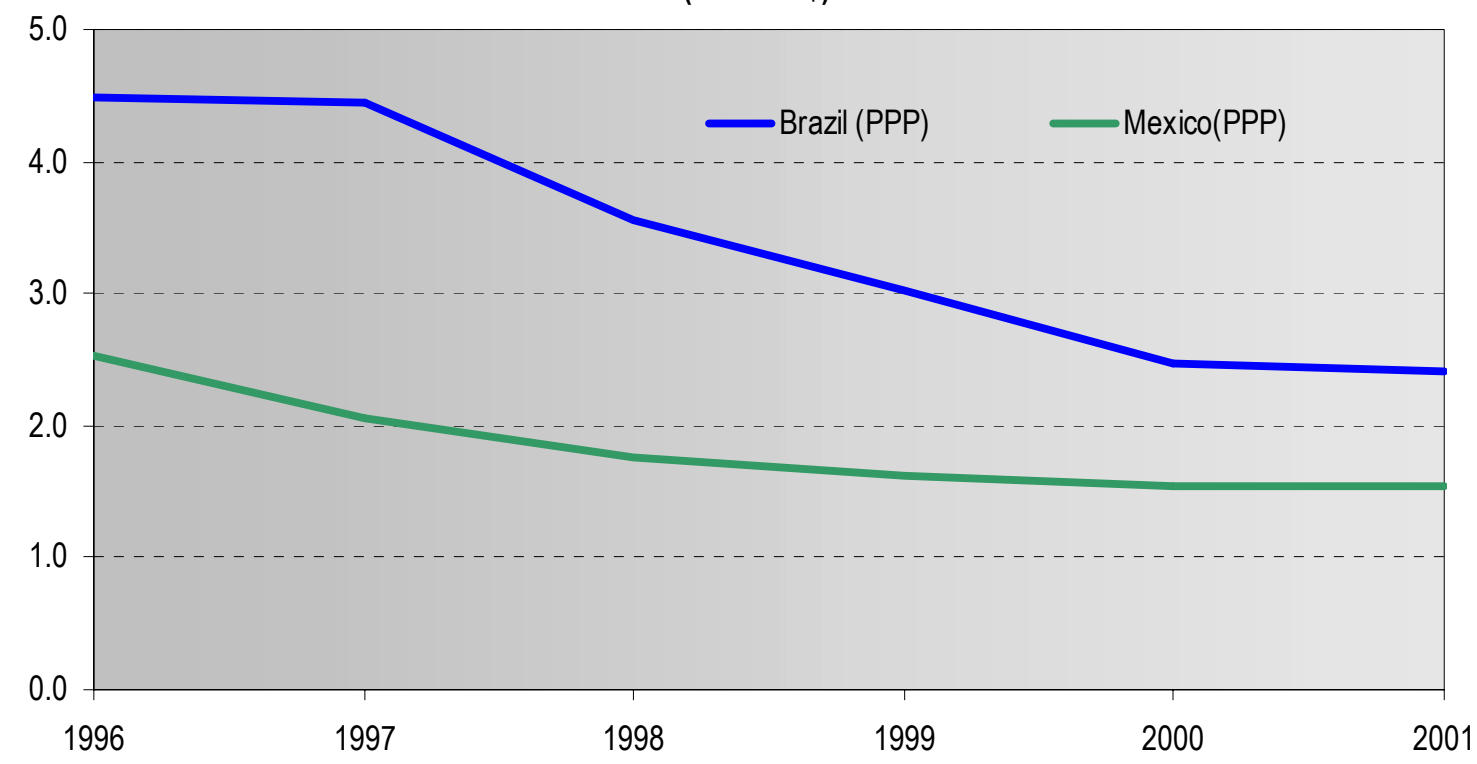

Source: Penn World Tables 6. China Statistical Yearbook, IBGE and INEGI annual industrial surveys

The PPP data suggest a declining wage gap driven by falling real wages both in Brazil and Mexico and rising wages in China. Yet, the difference seems to have stabilized in the late 1990s in levels which still give China a substantial advantage over the largest and most industrialized economies in the region. Moreover given China's present employment structure (Figure 6), this advantage might linger for quite some time to come despite China's breakneck growth (an annual average of 9.3 per cent in 1990-2002, CSY 2003). With 51 per cent of its labor force still in the primary sector, China seems to be far from it "Lewisian point", a stage in which rapid manufacturing growth exhausts the excess supply of labor in the primary sector and wages start grow faster than productivity. 


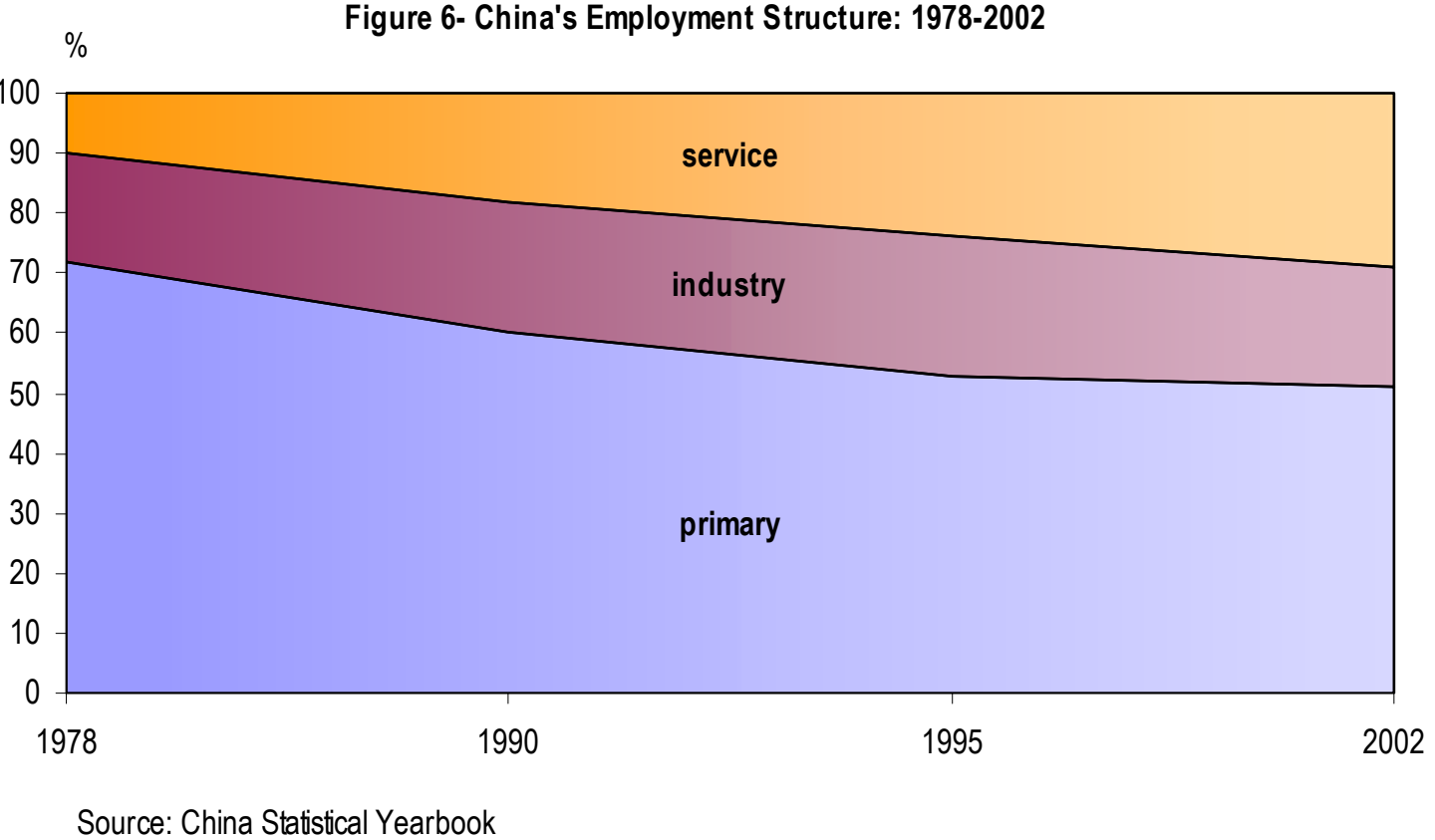

Productivity-- The second type of challenge is of a "Ricardian" nature since it is related to productivity (technology) and not endowments. It could be argued that China's wage advantage, as in the textbooks, reflects the low productivity of its manufacturing sector and therefore would not be a competitive advantage. Hard facts on productivity levels across countries, though, are difficult to find, not least because of the methodological difficulties involved. Mckinsey (2003) is one of the rare attempts in this direction and the results do not offer LAC great comfort. As shown in Figure 7, labor productivity does seem to be lower in China than in Mexico and Brazil in most sectors, but the difference is in general substantially lower than the wage gap. To make things even more complicated, the evidence available indicates that labor productivity has been growing much faster in China than in LAC, which suggest that latter's productivity edge will be wiped out sooner rather than later. 
Figure 7- Labor Productivity in China and Selected

Countries. 2001.

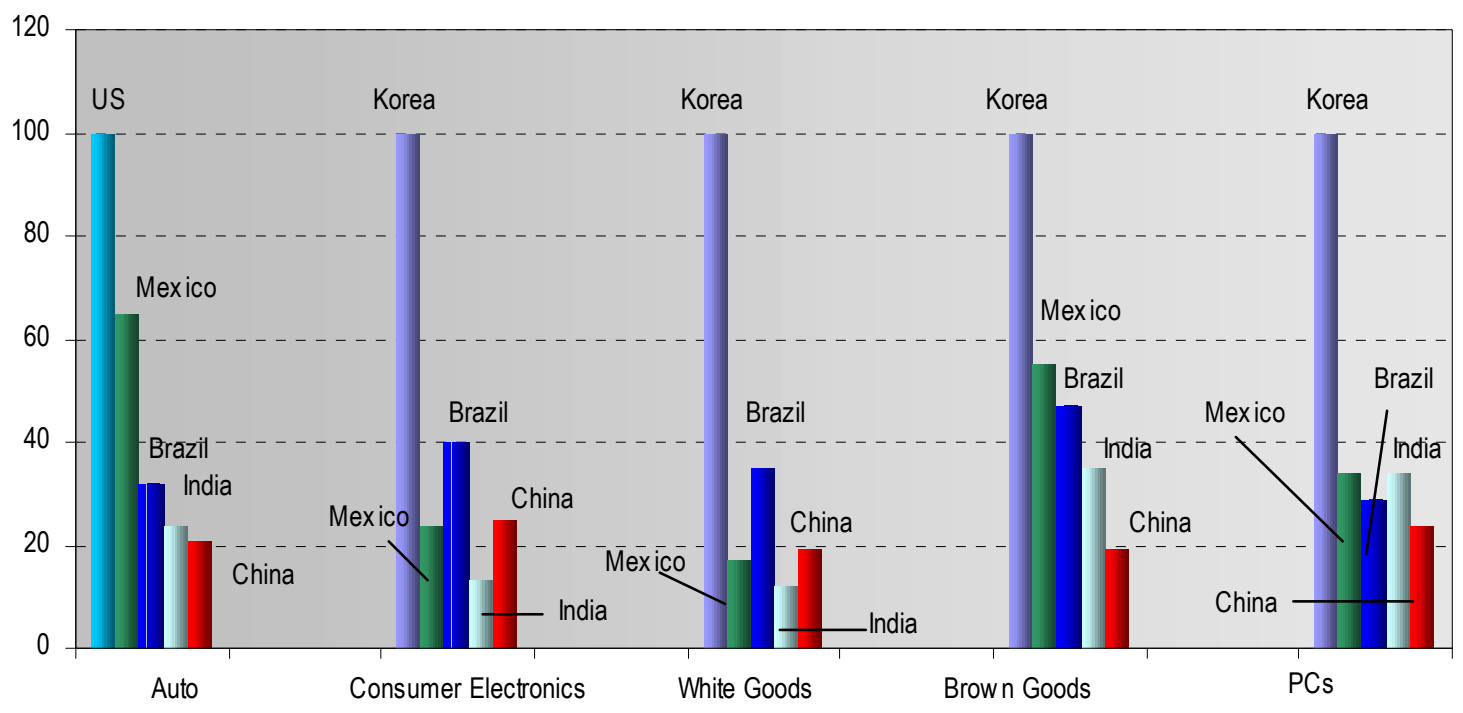

Source: McKinsey \&Co 2003

Figure 8 shows that Brazil and Mexico, despite their good results in the 1990s, were totally outperformed by China, which has even increased its lead since the turn of the decade. These results suffer little change when a more reliable exfactory deflator (see Young 2003) is used to calculate China's productivity growth. China's superior productivity performance in the last decade is also confirmed by firm level data (Figure 9), usually a more reliable source of information. 
Figure 8 - Labor Productivity in Manufacturing: China, Brazil and Mexico (valued-added per worker, national accounts data. 1990=100).

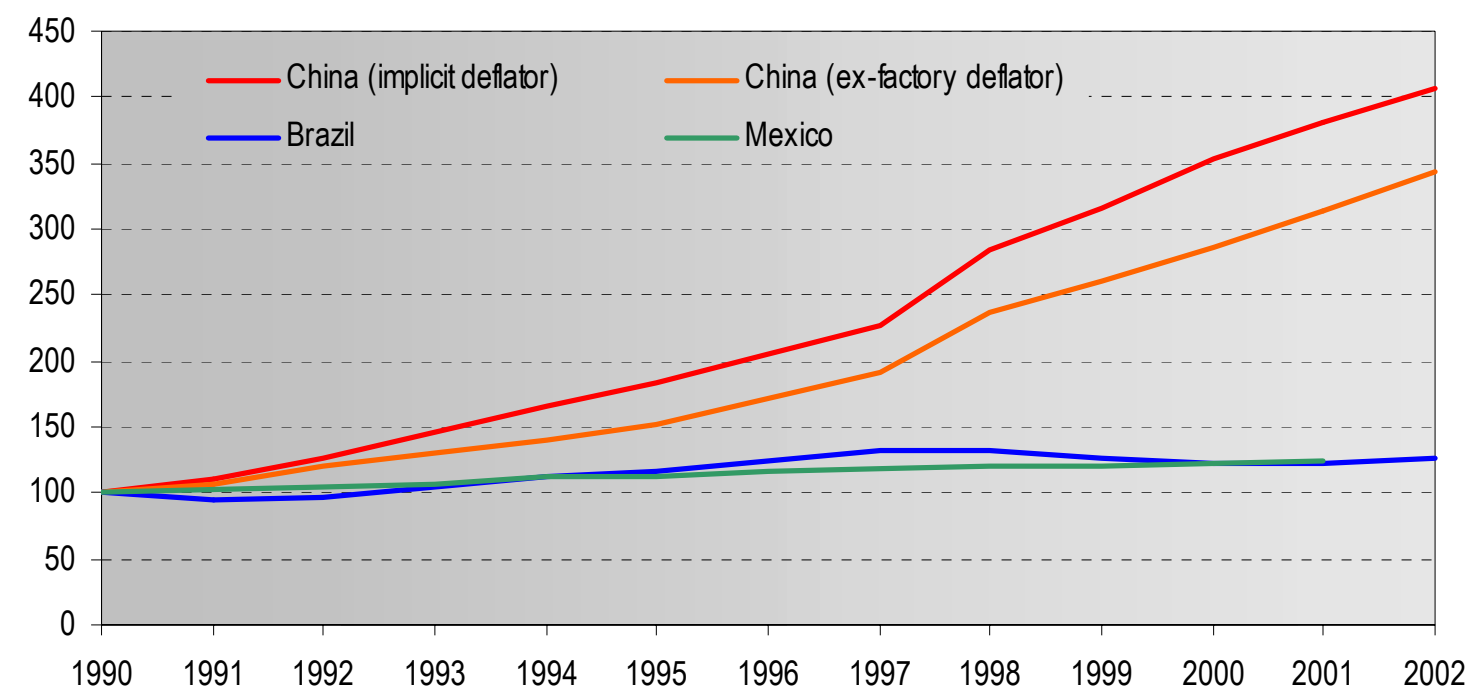

Source: statistical offices

Figure 9 - Labor Productivity at the Firm Level: China, Brazil and Mexico. Annual Average (\%)

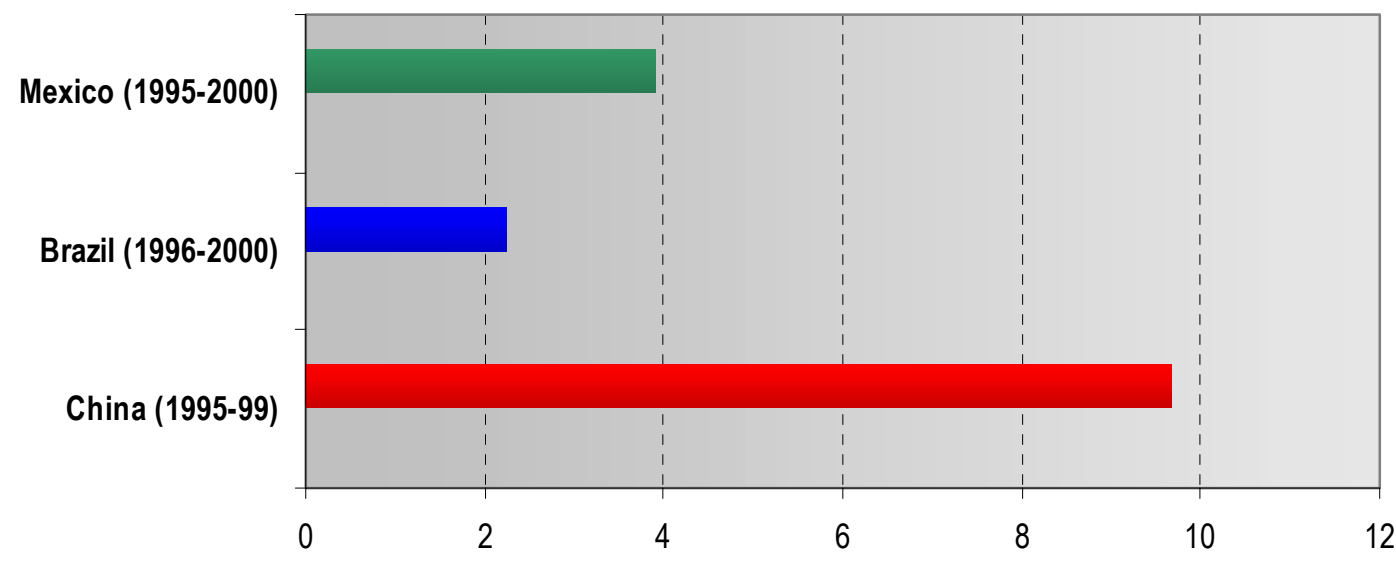

Source: Lopez-Cordova and Moreira (2004) and Hu, Jeffeson, Xiaojing and Jinchang (2003)

One might raise the issue that China's impressive performance might be just the result of capital deepening--an increase in the number of machines per worker. This possibility is particularly relevant for a country that has been investing close to 40 per cent of its GDP. Yet, total factor productivity estimates, notwithstanding their huge variance and methodological flaws, do not suggest 
that China is following in Soviet Union's footsteps. They tend to confirm China's edge over LAC, although the gap is not always as large as suggested by the labor productivity data.

Young (2003), for instance, using official national accounts data, estimates an impressive 3.0 percent per year TFP growth in 1978-98. The author argues, though, that the use of alternative and arguably more reliable deflators brings this result to a moderate 1.4 percent per year. To put these figures into perspective some of the TFP estimates for Latin America (e.g. IDB 2001 and Loyaza et al. 2002) point to an average negative growth in the 1980s and 1990s, although with a large variance among countries. The best performers in the region, Chile and Argentina, reached close to 2 percent TFP growth, but that was only in the 90s. Young's 1.4 percent result for China appears to be at the bottom of the range of estimates available. Other authors such as Wang and Wei (2004), also working on national accounts data, estimate a 2.3 percent TFP growth per year, which is a considerably better result given that includes the pre-1978 reform years (1952-1998). Li (2003), using both national and provincial data, finds an even higher estimate, putting TFP growth at 3.4 per cent in the post-reform years. Hyetens and Zebregs's (2003) estimates are in the 2.5 to 2.8 percent range for 1979-89 and within 2.6 to 4.0 percent for 1990-98. Unlike Young, none of these authors try to adjustment the official data.

The estimates based on sectoral or firm level data usually point to higher levels of TFP growth. For instance, Jefferson et al. (1999) estimates a 2.5 percent TFP growth per year for state and 3.4 percent for collective industrial enterprises in 1980-92. Jefferson et al. (2000), also using firm level data for manufacturing, estimate a 2.8 percent TFP growth per year in 1980-96. Roughly comparable estimates for Latin America usually suggest, with a few exceptions, a more modest performance. On Mexico, Tybout and Westbrook (1995), covering the first period of the trade liberalization (1986-90), puts the TFP annual growth at 
1.8 percent. Lopez-Córdova and Moreira (2004) puts the same figure for the NAFTA period (1993-1999) at 1.1 percent. On Brazil, Muendler (2004) estimates a 0.4 percent of TFP annual growth during 1986-98, and Lopez-Córdova and Moreira (2004) finds annual increases of 2.7 percent for the second half of the nineties.

Scale-Alongside endowments and productivity stands the scale challenge. Even though China is not (yet) a rich country (its per capita income of close to US\$ 1000 in 2003, put it among the lower middle income countries), it seems to fit almost all definitions a large country. The population, as mentioned before, is the largest in the world; has a surface that is roughly as large as the United States and 15 per cent larger than Brazil; and has a US\$1.3 billion economy, which is edging closer to the size of the entire LAC economy (US\$1.6 billion). Chinese exports, at US\$365 billion, are already higher than those of LAC as a whole. The PPP figures are even more impressive, putting the Chinese economy only behind that of the United States. The largest Latin American economy in PPP termsBrazil-is ranked 9th, with approximately 20 percent of the size of the Chinese economy. 5

Apart from the standard advantages of a large country in terms of things such as public goods (see Alesina, Spolaore, Wacziarg 2004), its sheer scale gives China an important edge in capital and technology intensive industries, because of the possibility of: (a) translating high fixed costs (equipment or R\&D) into low unitary costs; (b) benefiting from the increasing returns associated with learning and the creation of knowledge; and (c) overcoming indivisibilities or pecuniary externalities associated with increasing return technology (Murphy, Shleifer and Vishny 1989). The advantages of size, which are maximized by the country's 
exceptional growth record, also operates as a magnet to foreign direct investment (FDI), which boosts investment, brings technology and therefore, reduces China barrier to entry in capital intensive and technologically sophisticated industries. Since the early nineties China has been ranked as the number 1 destination for FDI in the developing world, with flows which reached US\$53 billion in 2002 (See UNCTAD 2003).

The government role--The fourth and final challenge lies on the role of government in the Chinese economy. While LAC was busy dismantling the interventionist apparatus of the ISI era, China was entering the world market with a policy regime that bore all the hallmarks of its East Asian neighbors, notably Japan, Korea and Taiwan. That is, a policy regime that involved heavy government intervention in the product and factor markets to support industrialization and exports. The fact, though, that the Chinese regime was built upon the foundations of a socialist economy has taken the government role well beyond what has ever been experienced anywhere in East Asia.

It is beyond the scope of this paper to make a detailed analysis and description of China's policy regime (for that see, e.g. Naughton 2004). Yet, it is worth noting that Chinese manufacturing firms, since the inception of the new regime in 1978, could count on "perks" such as: (a) an "unlimited" supply of credit, provided by state banks, at rates likely to be well below the opportunity cost of capital; (b) a public funded national innovation system, which has contributed to diffuse knowledge and reduce the costs and risks of R\&D (Dalhman and Aulbert 2001); (c) a very lax regulation of intellectual property rights, which has reduced the costs of imitation and absorption of foreign knowledge; (d) in the case of a substantial, though declining, number of firms, a direct access to treasury coffers

${ }^{5}$ All figures are for 2002, except for PPP data, which is for 2003. See WDI. The figures for the size 
guaranteed by their main shareholder, i.e., the Chinese government and; (e) even more generous financial, fiscal and other unorthodox benefits to the "national champions"-- firms belonging to "pillar" industries. ${ }^{6}$

Chinese firms have also lived under a dual or selective trade regime that would grant exporters free access to imported inputs at international prices, but that would severely restrict import competition in the domestic market. The regime has also been selective in terms of ownership. Foreign firms have received a very unorthodox treatment, although not unprecedented by East Asian standards. While LAC was adopting national treatment and phasing out local content and export requirements, China was marching in the other direction, going as far as prohibiting FDI in "strategic" sectors, though to be the preserve of local firms. On the "carrot" side, China has distributed lavish fiscal incentives to foreign firms under regimes such as the Special Economic Zones, at time when these practices were being considered costly and ineffective in LAC.

There is no doubt that over the years, China's policy regime has moved towards a more market-oriented approach, particularly after the WTO accession in 2001. For instance, China has made a series of commitments to: gradually eliminate trade-related investments measures; to unify and liberalize its trade regime; to liberalize FDI in sectors such as banking and telecommunication (WTO 2003). Yet, there is no sign that China is prepared to go as far as LAC in renouncing government intervention. As of the first quarter of 2004, 59 percent of total investment was still made by government entities (NBS-China). The financial sector continues to be dominated by state banks, which, as pointed out by

of the economies are based on GDPs.

${ }^{6}$ Nolan and Zhang (2002, p.2090) presents a list of those benefits: "tariffs, nontariff barriers, including limitations on access to domestic marketing channels, requirements for technology transfer and to subcontract to selected domestic firms as the price for market access; government procurement policy; government selection of the partners for major international joint-ventures; preferential loans from state banks; and privileged access to listings on international stock markets." 
Naughton (op cit p. 12), "continue to be somewhat responsive to the policies and projects of government officials at the national and local levels."

Perhaps even more revealing, the Chinese government had no qualms to announce recently that it is formally promoting 3 sectors, two of then in the manufacturing area: semiconductors, automobile and software (Naughton op cit). Not even in the reform of the trade regime, liberalization can be taken for granted. For instance, a recent report by the United State Trade representative (USTR 2003) has flagged a number of areas where reform has fallen well short of what has been promised. Among them trading rights and distribution services, import and export regulation, non-tariff measures and national treatment. Another worrying sign was given by the European Union, which has denied China the status of a market economy (People's Daily June 30 2004).

Whether or not these interventionist policies are behind China's take-off or whether or not they guarantee or compromise China's long-term growth is already the stuff of a prolific policy debate, which, as with other East Asian tigers, is bound to be inconclusive, not least because economists have yet to find a satisfactory way of dealing with counterfactuals. Yet, from LAC manufacturers' point of view, the omnipresence and generosity of the Chinese state has a very practical and immediate implication, which is to heavily tilt the playing field in favor of their Chinese competitors, in a scenario where they already face endowment, productivity and scale disadvantages.

\section{Trade impacts}

Does the trade data confirm the severity of the Chinese challenge? The answer is a qualified yes. Qualified because the assessment of trade impacts involves complex general equilibrium issues as well as methodological problems stemming from aggregation bias and product differentiation, particularly in the 
case of manufacturing goods. Yet, having these limitations in mind, the picture that emerges is not very comforting for Latina American producers.

Shifting shares--A simple way of approaching the issue is to look at what happened to market shares of manufacturing exports in the last two decades. As can be seen in Figure 10, the eighties were disastrous to LAC, which eventually staged a recovery in the nineties, driven particularly by Mexico. Yet this recovery was not enough to match China's performance, which by the end of the nineties had roughly twice the market share of LAC's biggest manufacturing exporter, i.e. Mexico. The picture also shows the yawning gap between LAC and the East Asian Tigers.

Figure 10-World market shares for manufactured exports: selected countries and regions

$1981-2002(\%)$

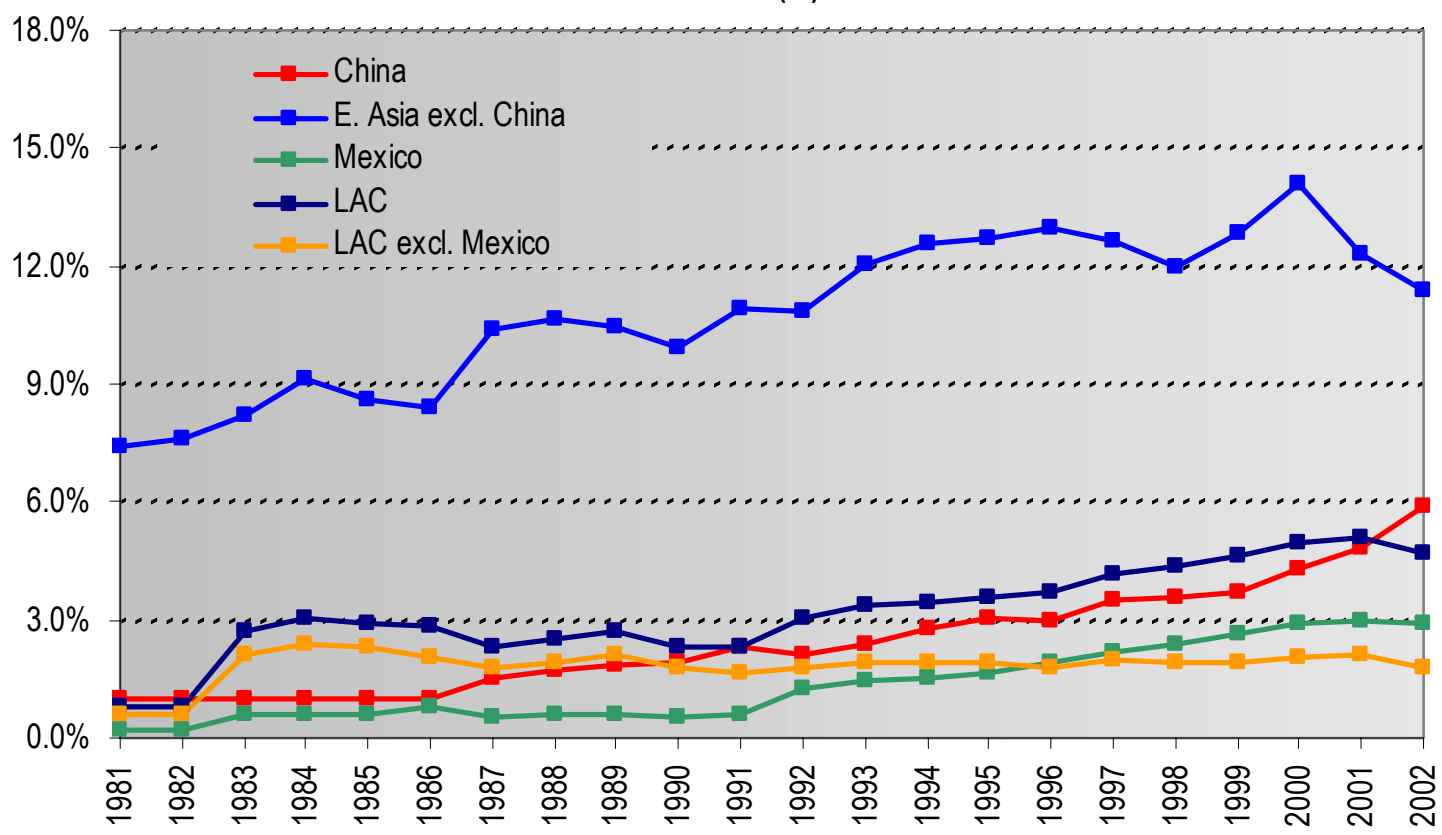

Source: Comtrade

Note: Manufacturing is defined as SITC 5 to minus 68

An important issue, which cannot be answered by Figure 10, is the extent to which China's growing market share was built at LAC expense. Figure 11 offer 
an approximated answer to this question, using an approach suggested by Batista and Azevedo (2003). To overcome the lack of data on the elasticity of substitution between Chinese and LAC exports, LAC' losses of market share in any product, market and period is attributed to China according to the latter's participation among the countries which gained market share in that particular product, market and period. For instance, if LAC looses market share in textiles in the US market in the 1990s, this losses will be attributed to China, if China had gained market share in that product, market and period. If Korea and China were the only countries that gained market share in textiles, and China has 50 percent of the gains, 50 percent of LAC losses will be attributed to China. ${ }^{7}$ Given that, for the majority of industries, products are highly differentiated, the accuracy of this exercise depends heavily on the data level of aggregation. Yet, limitations on data availability for a number of countries does not allow the analysis to go beyond the 5 digit level of the Standard International Trade Classification (SITC). The results, then, particularly at the product level, have to be taken with a pinch of salt.

\footnotetext{
7 Formally $L_{j k i}=L_{j i} *\left[\frac{G k i}{\sum_{k=1}^{n} G k i}\right]$, where $L_{j i}=\left(m s_{j i}^{t-1}-m s_{j i}^{t}\right) * M_{i}^{t}$ and $m s_{j i}^{t-1}>m s_{j i}^{t}$

$L_{j k i}$ is the loss (current US\$) of country $\mathrm{j}$ to country $\mathrm{k}$ in the product $i, G_{j}$ is the gain of country $j$ in the product $i, m s_{j i}^{t}$ is the market share of country $j$ in the product $i$ in time $t$ and $M_{i}^{t}$ is world imports of good $i$.
} 
Figure 11 - LAC's World Market losses to China by technology intensity (1990-2002).

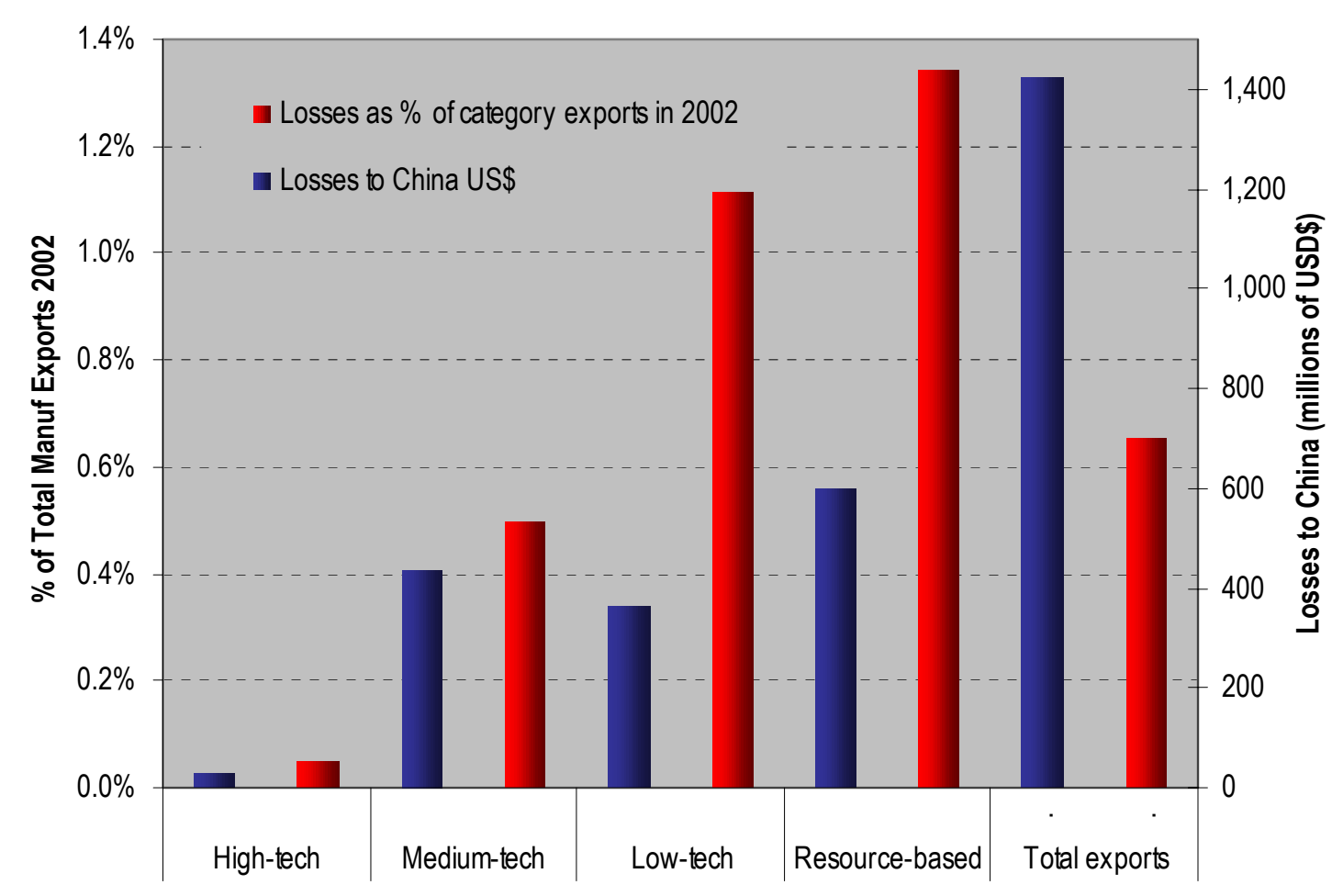

Source: Comtrade with author's own calculation.

Figure 11 suggests that LAC losses to China in the World Markets in 1990-2002 were on the whole relatively small, reaching 0.7 percent of the region's total exports in 2002 (US\$ 1.4 billion). ${ }^{8}$ Contrary to what could be expected from a cursory factor endowment analysis, the highest losses were not concentrated on low-tech, labor intensive goods, but in natural-resource intensive goods, suggesting that LAC should be prepared to face competition from China on the whole spectrum of factor-intensity goods.

Yet, it is worth noting that distortions such as the Agreement on Textiles and Clothing (ATC)--which freezes markets shares in textiles and apparel in the main

8 See Lall (2000) for details of the classification. There was also a non-manufacturing category included in the exercise, primary products, which did not reveal any losses in the period. 
world markets--and LAC's protection of its own low-tech, labor-intensive industries might be behind the relatively small losses in the low-tech sector. The end of the ATC in 2005 could drastically change this picture, particularly for countries in the region whose industrialization was based on the fragmentation of the production process, taking up the more labor-intensive stages of the production chain, such as Mexico and countries in Central America (see e.g.

Figure 12 - LAC's Annual World Market losses to China

(1990-2002, SITC 5 digits)

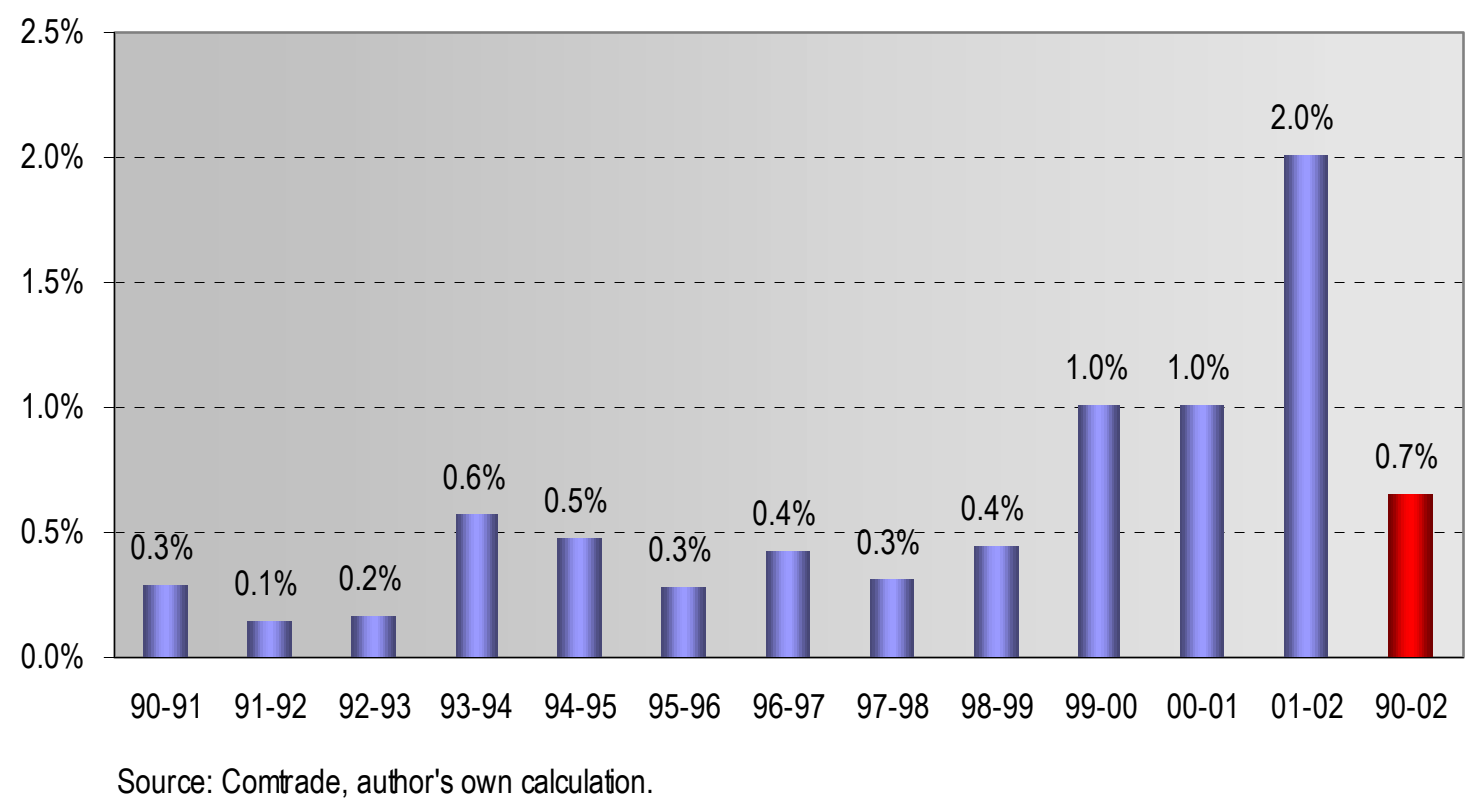

Condo et al. 2004 and Nordas 2004).

Figure 11 for comparing two points in time does not tell much about the trend behind the losses. This is shown in Figure 12 and, as it can be seen, overall losses might have been relatively small, but the trend suggests difficult days ahead. Figure 11 also blurs somewhat the picture when it averages the performance of LAC's diverse countries and subregions. Figure 13 gives a more detailed account of these performances and it is clear that the more resource-intensive countries in South America (Andean Community and MERCOSUR) seem to have been the more affected. Central America (Central America Common Market-CACM) and 
Figure 13-LAC World Market losses to China by selected countries and subregions, as a percentage of 2002 manufacturing exports (1990-2002, SITC 5 digits)

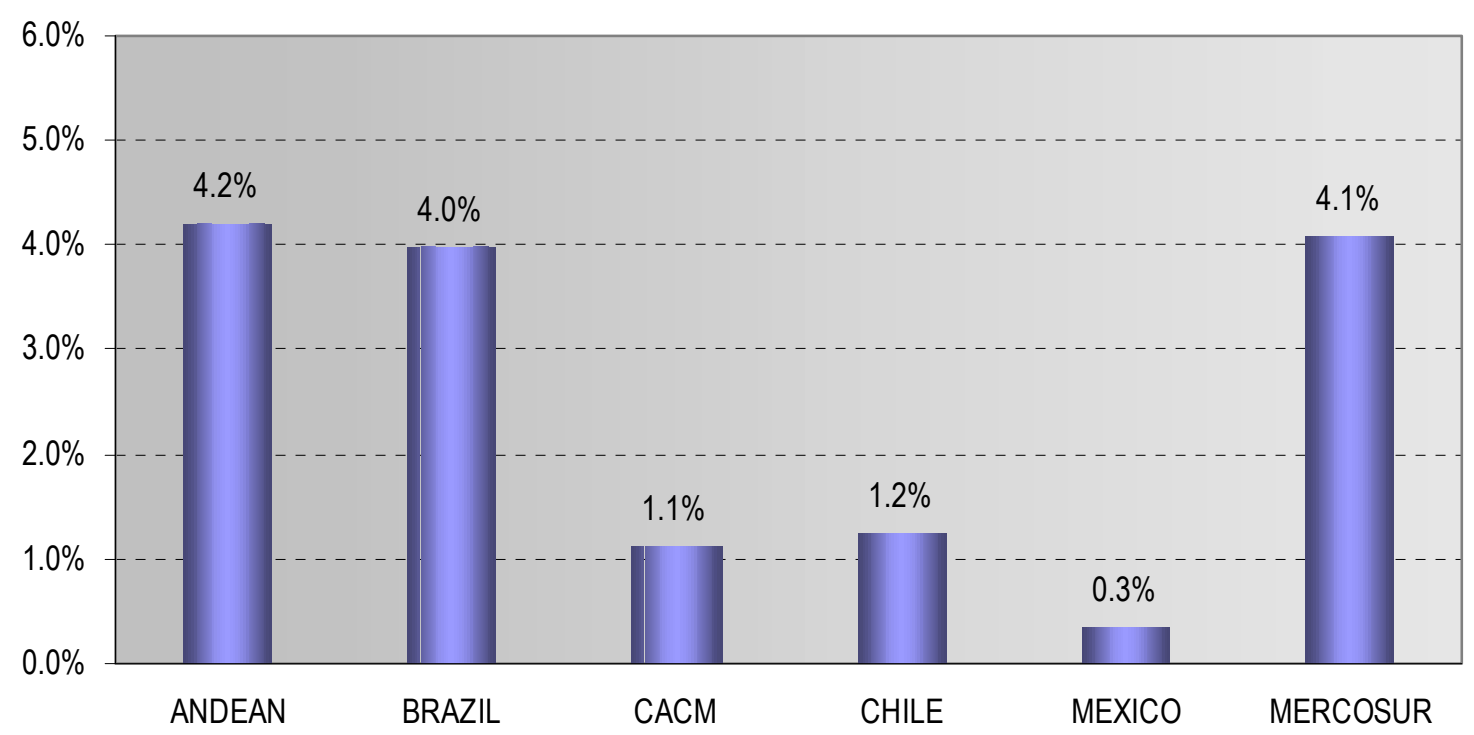

Source: Comrade, author's own calculation.

Mexico apparently used preferential agreement and higher MNF protection for low-tech, labor-intensive industries as a shield against Chinese competition (see Lopez-Cordova 2004). Yet, annual data shows that Mexico's and Central America losses, as with LAC as whole, have been mounting particularly after 1999.

Figure 14 shows that LAC's most affected markets were outside the region, implying that it has yet to suffer the full-blown Chinese impact on its main markets, particularly on its domestic market. Reliable data on market penetration for the entire region is difficult to come by, but trade flows suggest that China's moderate presence in LAC's domestic manufacturing market is changing rapidly. Figure 15 reveals a rapidly increasing Chinese share of manufacturing imports in all LAC's subregions, which, however, have still a long way to go to match the situation in the US manufacturing market. Data on import penetration for Brazil and Mexico (Figure 16) tend to confirm this picture of a small but rapidly increasing impact of Chinese imports on local manufacturers. In case of Brazil, whereas the country's import penetration as whole has been declining 
since 1999 maxi-devaluation, Chinese penetration has moved in the other direction, increasing substantially, although from a small base. In Mexico, the growth of China's imports has been outpacing that of the rest of the world by a large margin since 1999.

Fig 14 - LAC's World Market Losses to China by Selected Markets, as a percentage of 2002 manufacturing exports (1990-2002, SITC 5 digits)

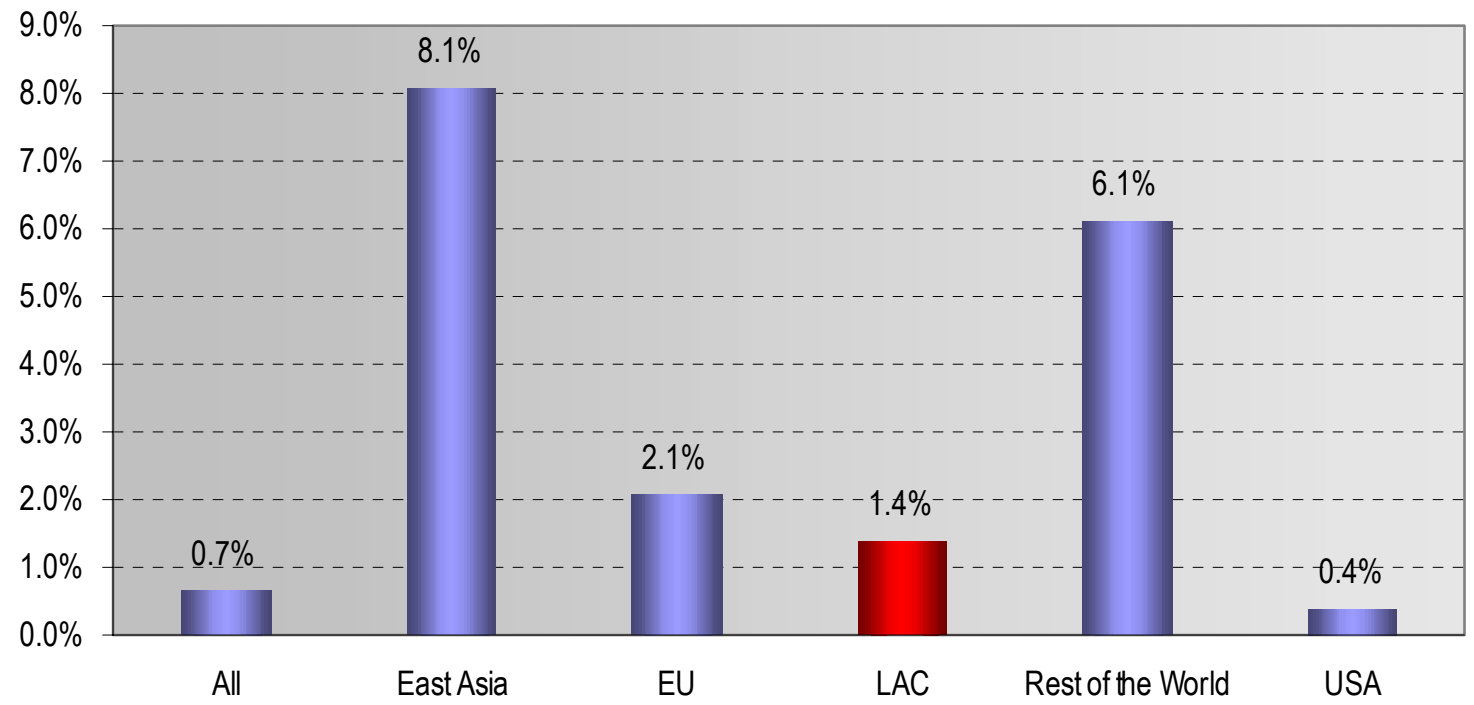

Source: Comtrade, author's own calculation.

Figure 15 - China's Share of Manufacturing Imports in Selected Sub-regions and Countries. 1990-2002

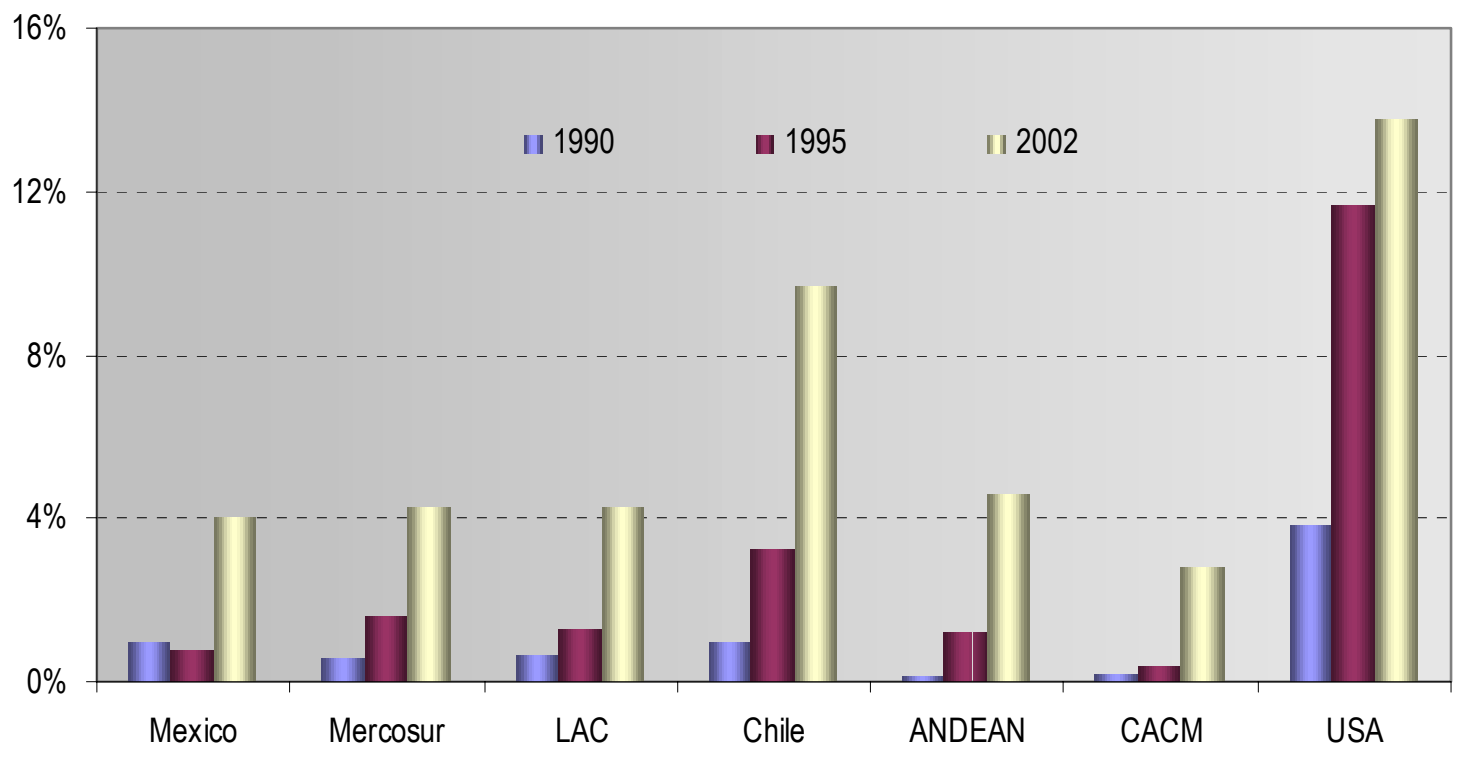

Source: Comtrade 
Figure 16 - Brazil's and Mexico Import Penetration* in Manufacturing goods.

World and China (1996 - 2003)

World \%

China \%

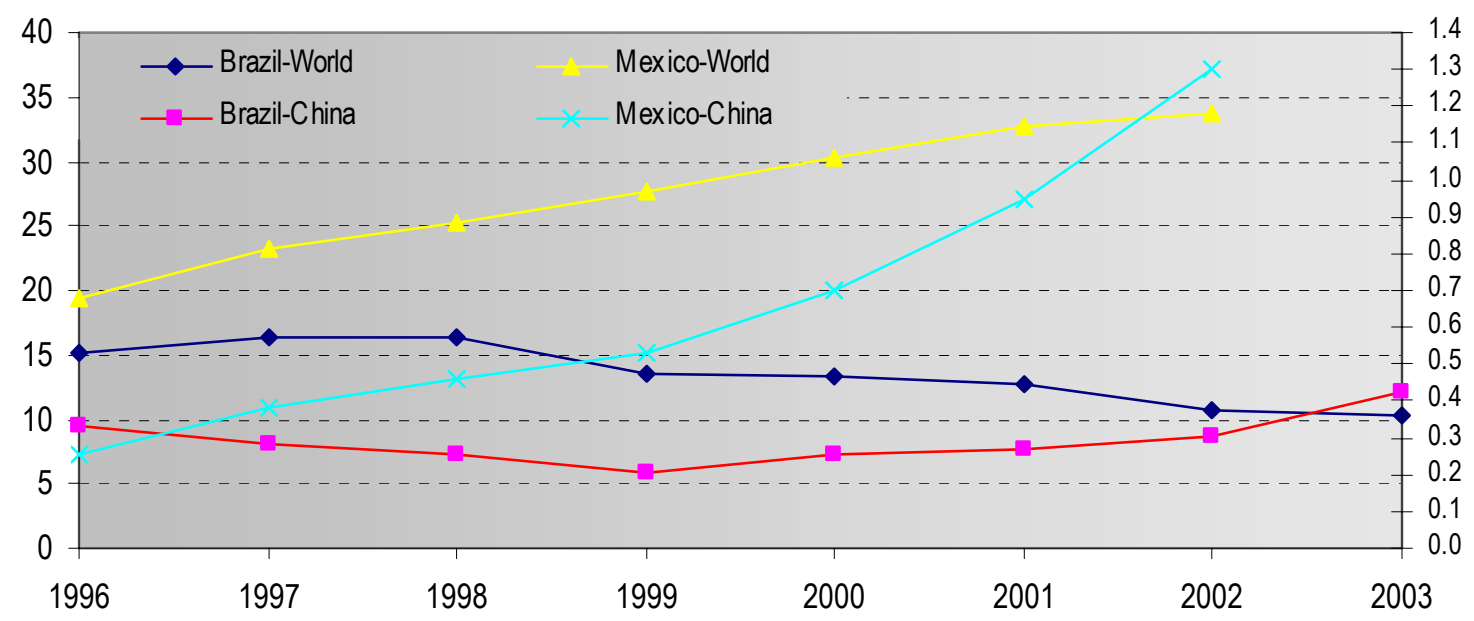

* Import divided by apparent consumption. Brazil's and Mexico's output data converted to US dollars using, respectively, 1998 and 1994 real exchange rate Source: own calculation based on IBGE and SECEX data.

Bilateral Trade--Another way of looking at trade impacts is to assess the volume and composition of the bilateral trade between China and LAC. LAC's exports and imports to China boomed since the early nineties, reflecting the market oriented reforms in China and in the region. Yet, exports lagged behind imports, producing an increasing trade deficit, which reached US\$5.7 billion in 2002, despite China's considerably faster growth. This figure hides, though, considerable differences among countries in the region, with resource-intensive countries such as Brazil, Chile, Peru and Argentina showing sizeable surpluses after 2001.

For the purposes of the present discussion, the composition of the bilateral trade is particularly revealing. Figure 17 shows that LAC's net exports to China are only relevant in primary products. It is marginally positive in manufactured goods intensive in natural resources and heavily negative in all the other categories of manufacturing goods. So, unlike China's trade with other developing countries in Asia, which is marked by an intensive intra-industrial trade (see Lall and Albadejo 2003 and Ahearne, Fernald, Loungani and Schindler 
Figure 17 - LAC Net Exports to CHINA by factor intensity.

US\$ million 1980-2002

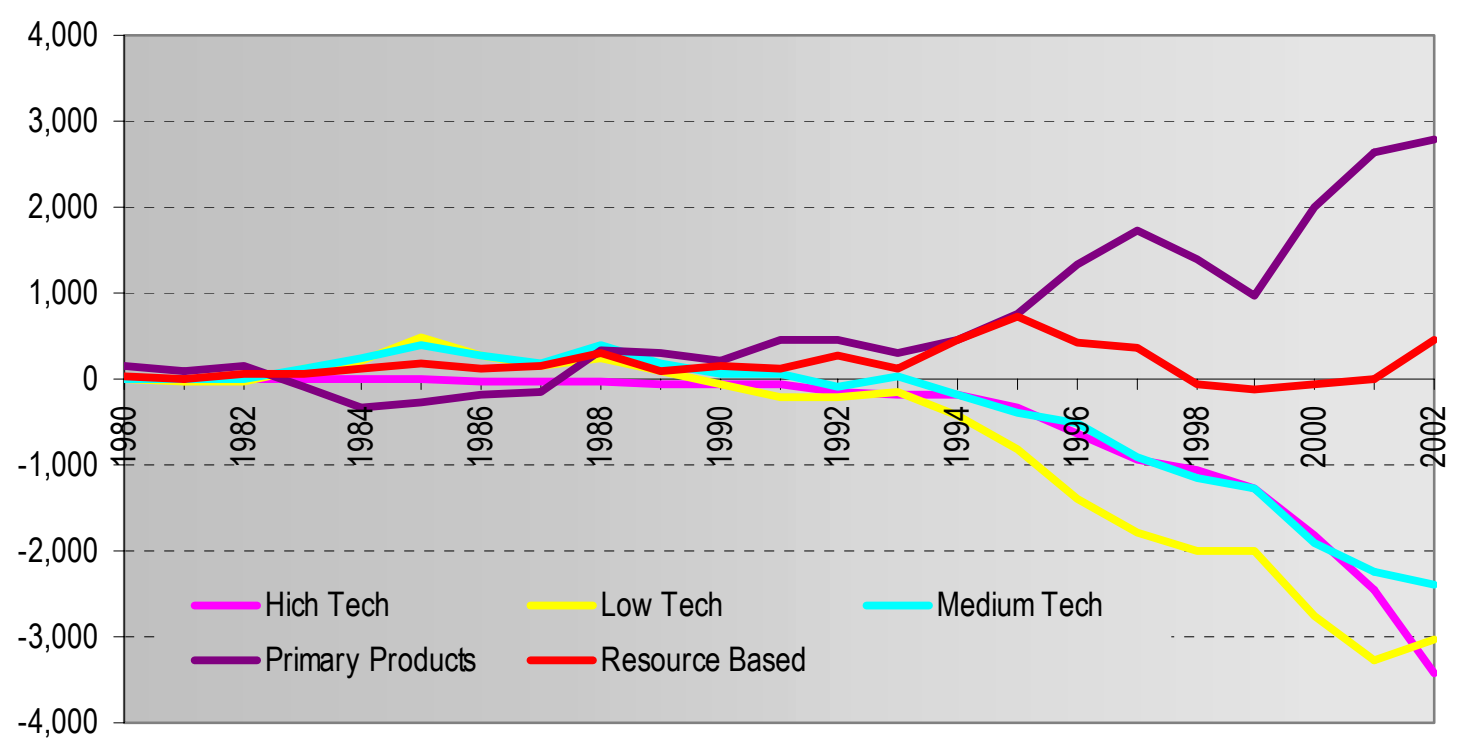

Source: Comtrade

2003), its trade with LAC seems to be heavily based on traditional comparative advantages, reinforcing a pattern of specialization, which, as discussed before, might not be growth enhancing.

In fact, as of 2002, LAC's share of China's total imports of manufacturing goods were a mere 1.2 percent, whereas ASEAN countries accounted for 8.5 per cent. One could argue that this is the inexorable result of geography and endowments, yet given the characteristic already described of China's trade regime and taking into account that the composition of LAC's net exports to the rest of world shows a much higher share of manufacturing goods, one should at least explore other possible explanations. For instance, both Chile and Brazil seems to face a more "visible hand" when trying to export more industrialized versions of natural resource products. Chile's has difficulties in exporting refined copper (Claro 2004) and Brazil, products such as soy oil and leather shoes (Abreu 2004). Likewise, ASEAN success in exporting manufacturing goods to China might be related to its engagement in the multinationals' global production chain and, therefore, they face the more liberal, export-processing, version of China's trade regime. 


\section{Export similarity}

Whereas shift-share analysis and descriptive trade statistics reveal a great deal of information about the past and the present, they do not say much about the potential trade impacts. Indices of export similarity can be useful in this regard and reveal the relative vulnerability of countries and industries of the region to Chinese competition in third markets. Among the several possible indices we picked the straightforward coefficient of correlation of the export composition. The use of alternative indices such as the Finger-Kreinin export similarity index (Finger and Kreinin 1979) does not change the main story. Figures 18 and 19 show the evolution of the coefficient of correlation in 1992-2001 of the largest Latin countries and sub-regions and China, for exports to the US and rest of the world markets (6 digits of the Harmonized System). ${ }^{9}$

In both markets the story is very similar and the main drivers of the change seems

Figure 18 - Coefficient of Correlation for Export Composition LAC-China: US market (HS 6 digits)

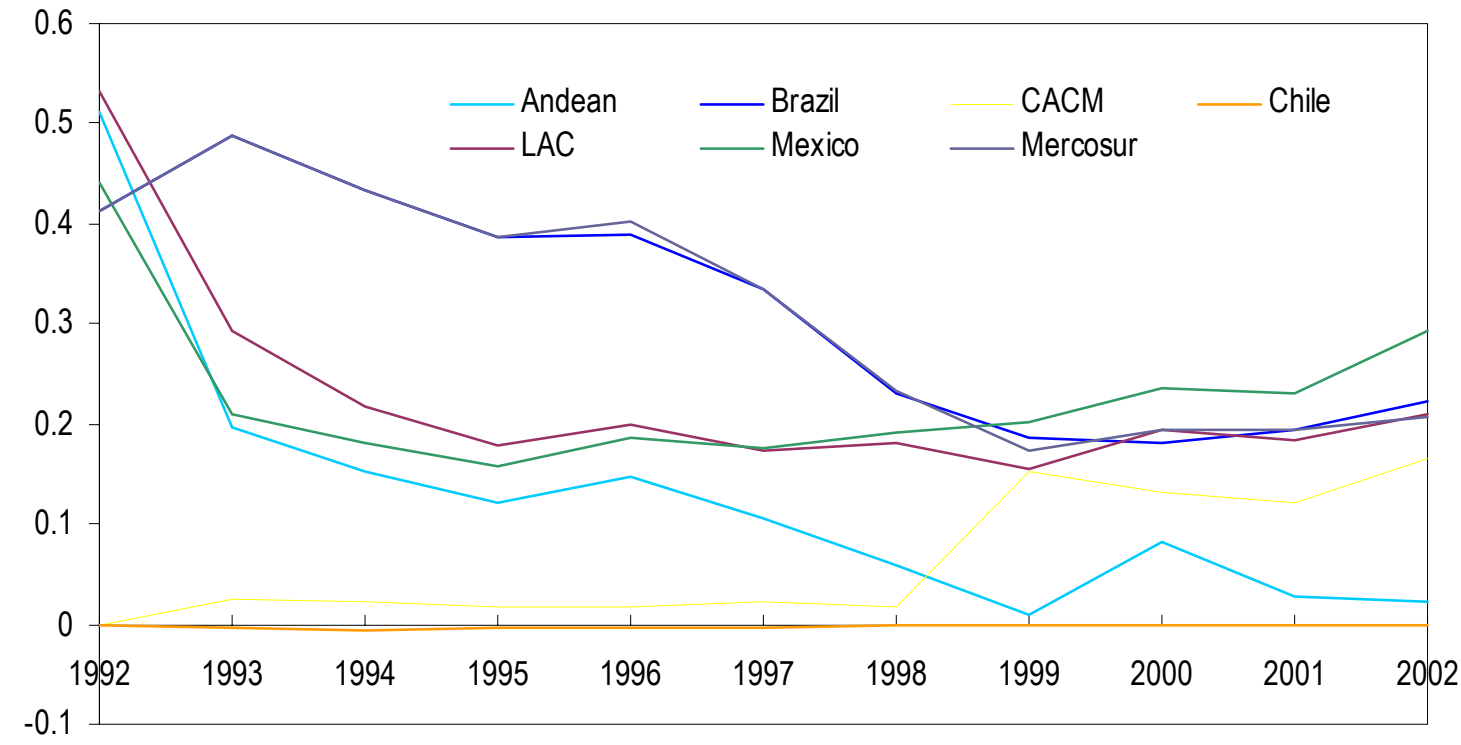

Source: Comtrade

${ }^{9}$ Changes in the product classification along the period and data availability prevented the use of a lower level of aggregation. 
Figure 19 - Coefficient of Correlation for Export Composition

LAC-China: Rest of the world (HS 6 digits)

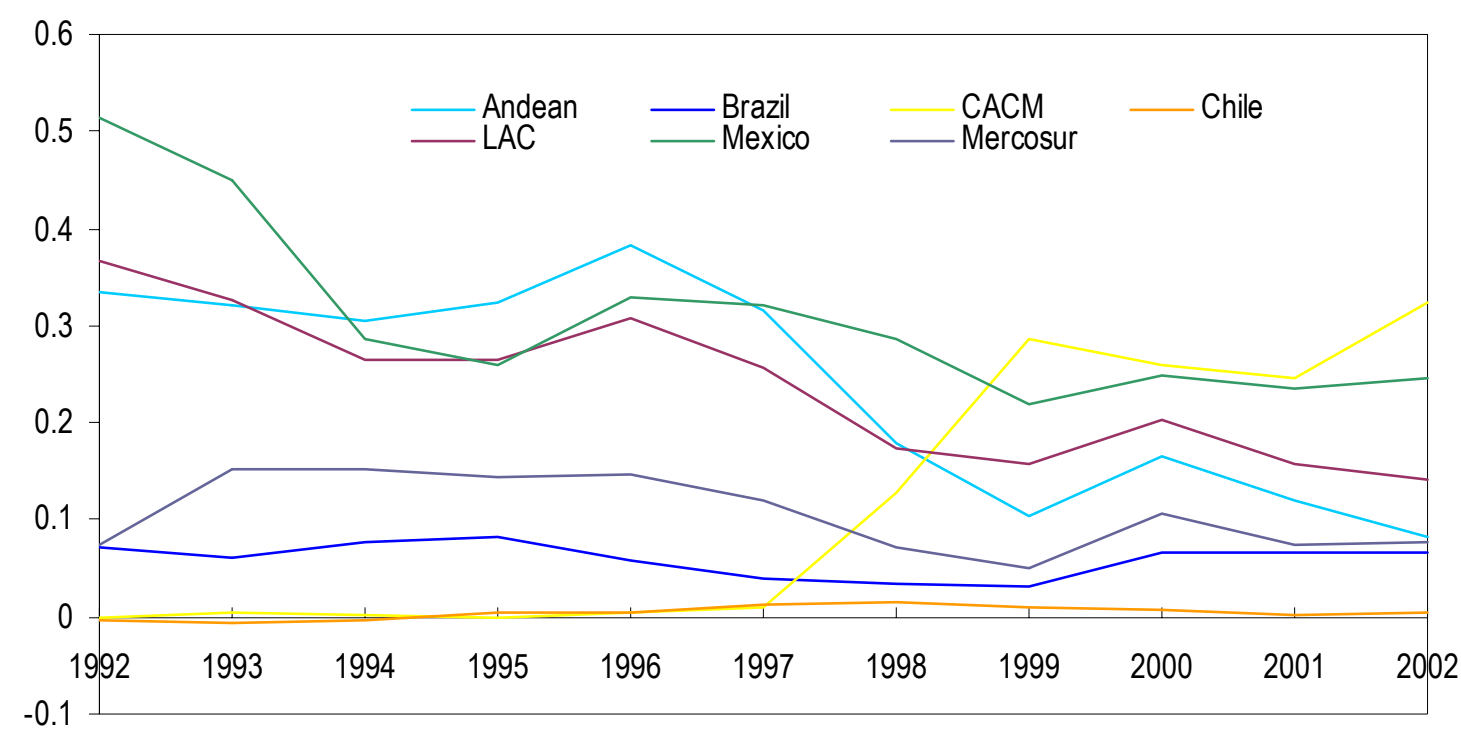

Source: Comrade

to be: (a) first and foremost, the rapid structural change of the Chinese economy throughout the 1990s--away from natural resources, labor intensive and on to capital and technology intensive goods, and its impact of the composition of exports; (b) the relative dynamism of the high-tech manufacturing sector in Mexico and in the CACM, driven by preferential trade agreements and; (c) little structural change and a export composition heavily based on natural resources or resourcedbased manufacturing goods in countries such a Chile, Brazil and in subregions such as the Andean Community and MERCOSUR.

For instance, the high share of oil in total Chinese exports in the early 1990s is behind the relative high initial correlation shown by Mexico and the Andean Community. As China becomes a net importer of oil along the decade and becomes heavily specialized in the exports of manufacturing goods (initially labor intensive, low-tech goods but gradually shifted into more capital intensive, hightech products), this correlation shifts into a declining trend. In the case of Mexico, the correlation starts to rise again in the mid-nineties, mainly in the US market, driven by the export boom and the change in composition towards more high-tech, capital-intensive goods associated with NAFTA. 
CACM experienced a similar pattern in both markets, but later in the decade and driven by FDI in sectors such as semiconductors, in countries such as Costa Rica. Brazil and Mercosur start with a relatively high correlation in the US market, based on the exports of resourced-based and low to middle-tech goods, but since they do not follow China's move up the technology and capital-intensity ladder, this correlation falls sharply along the decade. Their correlation also declined in the other markets, but given the lower share of manufacturing goods in exports to the rest of the world, the correlation was consistently lower than in the US market throughout the period. Finally, Chile's heavy reliance on natural-resource goods

Figure 20 - Coefficient of Correlation for Export Composition

LAC-China: Manufacturing, US market (HS 6 digits)

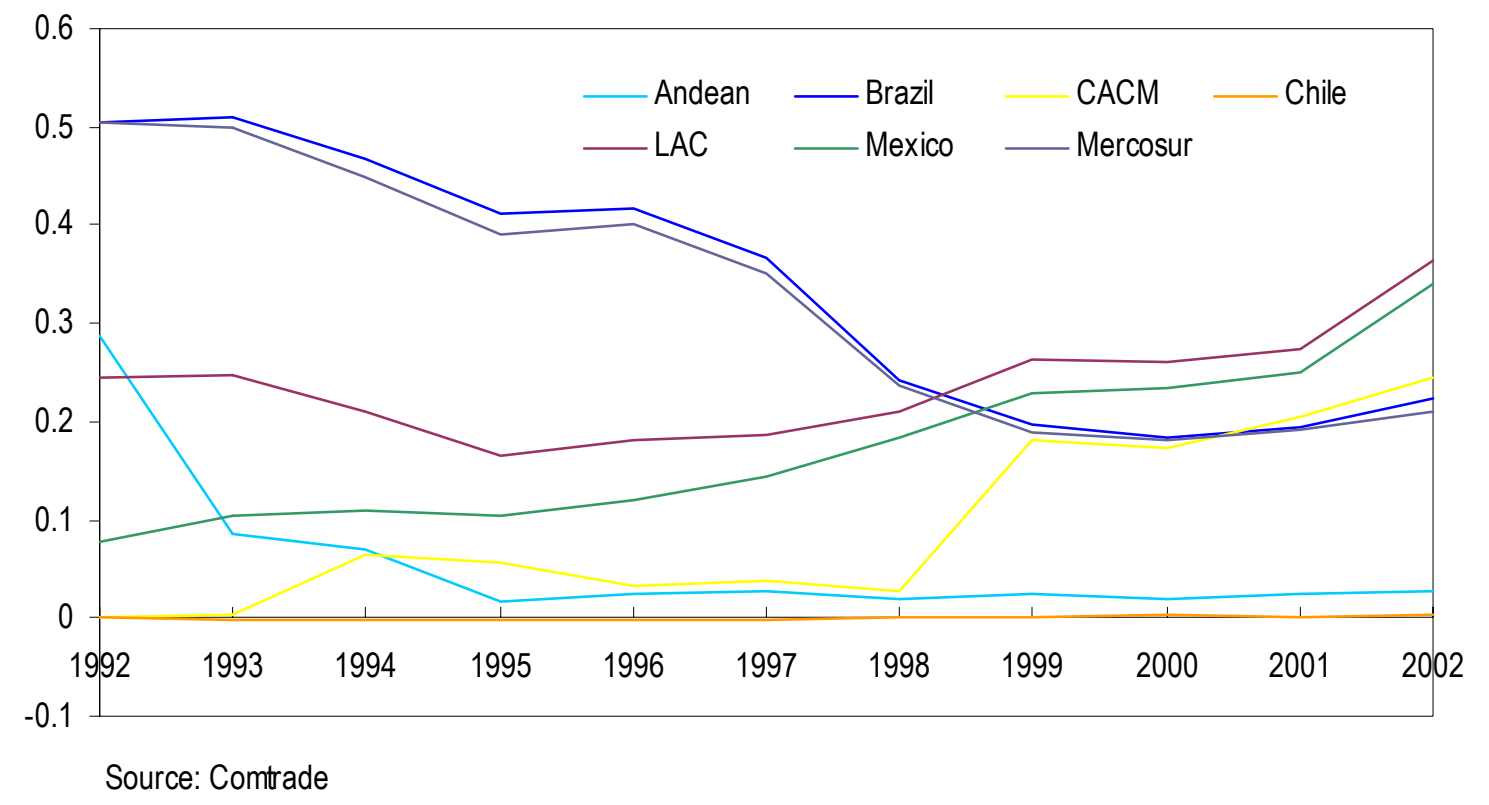

puts the country among the least vulnerable to Chinese competition in the region.

These movements on the level of direct competition with China become clearer when the main driver of the changes, i.e. manufacturing, is isolated. Figures 20 and 21 present the same correlation index between LAC and China for the US and the 
other markets, but taking into account only manufacturing goods. ${ }^{10}$ As it can be seen, this approach underlines: the rise of Mexico and CACM to the position of the most vulnerable countries in the region, in both markets; the declining vulnerability of Brazil and Mercosur and the very "safe" position of Chile and the Andean community.

Figure 21 - Coefficient of Correlation for Export Composition LAC-China: Manufacturing, Rest of the world (HS 6 digits)

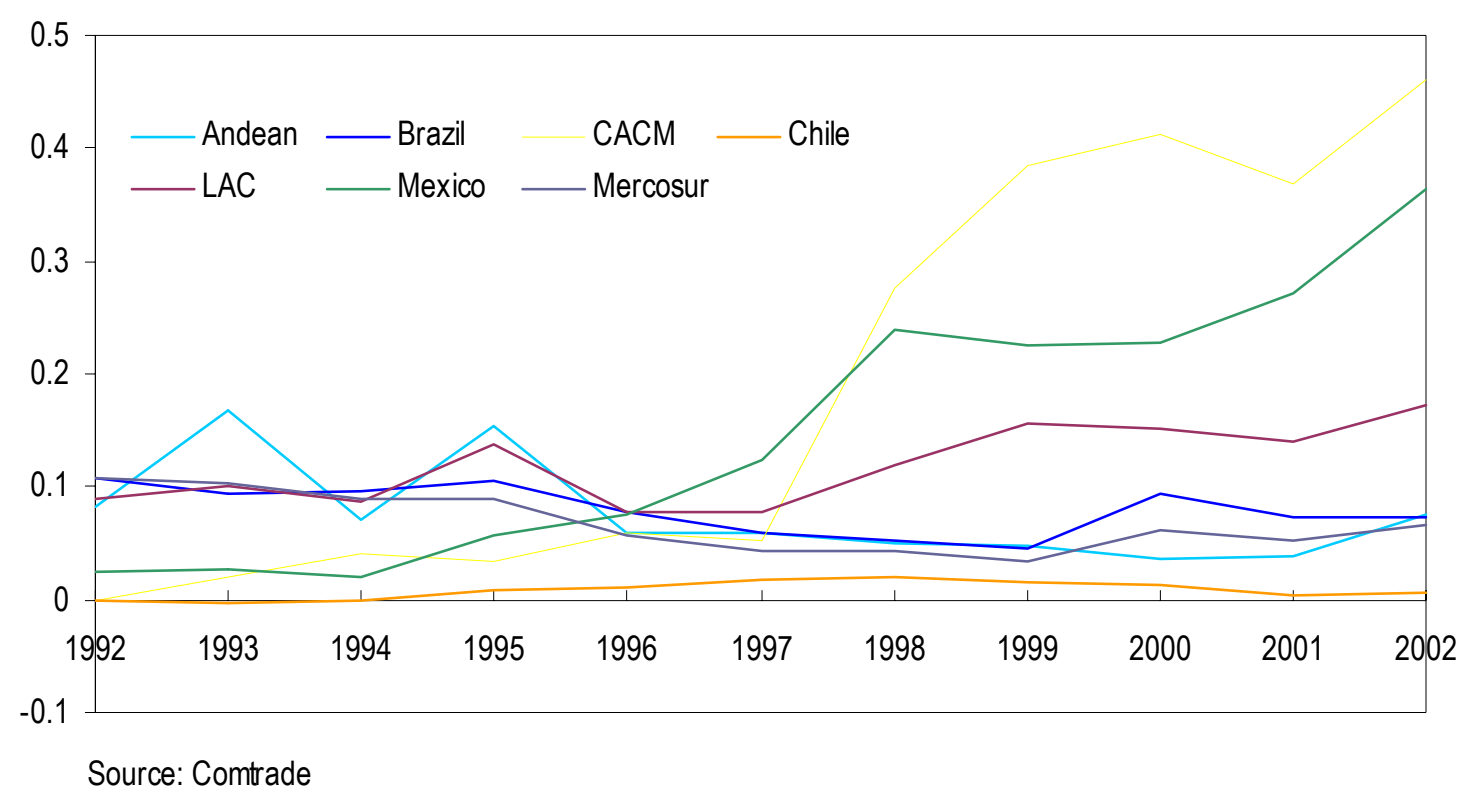

Though relevant, these figures should be interpreted with caution. True, Mexico and CACM are the most vulnerable in the region, particularly because they rely heavily on industries such as apparel, textile and electronics where China has huge comparative and competitive advantages. The more so, because they specialize on stages of the production chain that are highly labor intensive and can easily go east. Their shallow network of suppliers and relatively low technological capabilities add even more credibility to this threat. But the position of the other countries does not look comfortable either. If one accepts the premise that diversification into increasing return, human capital and technology-intensive

${ }^{10}$ Definition based on the usual SITC classification (sectors 5 to 8 except for the sub-sector 68), 
industries is good for growth, what they are seen is an increasingly congested field ahead, not least by China, which calls into question their prospects of a more diversified and dynamic economy.

\section{Conclusions}

Is there a future for manufacturing in Latin America? One thing we can say for sure is that China does not make this future any brighter. The combination of endowments, scale, fast productivity growth and an omnipresent state makes of China a formidable competitor to Latin American manufacturers and raise many questions about their future. This is particularly true in a world market already overcrowded by at least three generations of Asian Tigers and facing the prospects of others, such as India, to come. As Blum and Leamer (2004, p.569) put it "[...] the world is awash in countries competing to do mundane manufacturing tasks and that route towards progress is foreclosed by overcrowding."

This prospect would not be reason for concern if we could say, beyond any reasonable doubt, that manufacturing does not really matter for growth and development. Yet, both theory and evidence seem to suggest otherwise, at the very least, for the opportunities of diversification involved. The risks of a pattern of specialization based on natural resources are there for everyone to see, including with very concrete examples in the region. True, there are success stories, but they seem to be exceptions based on particular historical and institutional environments. This does not mean that the region should "turn its back" to natural resources or any policy of that sort. It just means that, on the basis of the evidence available, the region would be ill advised to renounce to a

converted into the harmonized system. 
well-proven road to prosperity, no matter how treacherous this road has become with the emergence of China.

Even if we leave China apart, the future of manufacturing in LAC is usually seen with pessimism on the grounds of geography and endowments. The tribulations of the sector on the last two decades seem to corroborate this view. Yet, geography and endowments do not tell the whole story. First, there was the legacy of the ISI era, which promoted industrialization beyond any economic rationale and underinvested in human capital. Second, there was the decades of macroeconomic volatility that were particularly costly to the tradable sector and, finally, there was the overreaction to the excesses of government intervention, which left manufacturers vulnerable to market failures and foreign targeting.

These are all policy-related factors and both theory and history give us hints that well-designed policies, backed by strong institutions, can overcome the restrictions imposed by endowments and geography. To put it differently, policies might change the endowments that matter for industrialization and growth, such as human capital and technological capabilities.

If seen through these lenses, the Chinese challenge might still look daunting, but not insurmountable. It all depends on the region's ability to pursue a policy agenda, which should aim at: a) the consolidation of the macro stability anchored on fiscally responsible policies and institutions; b) the formation of a large regional market to reduce de disadvantage of scale, particularly for the smaller countries, an issue where regional agreements might play a crucial role; c) the relaxation of excruciating credit-constraints on local firms, which are up against highly-leveraged Chinese firms; d) the enhancement of frail local technological capabilities (i.e. human capital), not only to boost productivity, but to increase the region's ability to differentiate its products and diversify its investments into externality prone and growth enhancing activities. 
Of course, this is easier said than done. As Stigltiz (2002, p.50) put it, "Unfortunately, we can say more about what is needed, than we can about how to create what needs to be created." There seems to be no doubt, though, that, to meet this challenge, the region will need a much more pragmatic approach to government, than it had during the nineties. It seems also clear that for a region with such a variety of country sizes, endowments and institutions, there must be a fair amount of "self-discovery" in policy-making, i.e.: "The specifics of how this [fostering industrial growth and transformation] can be managed is likely to differ from country to country, depending on administrative capability, the prevailing incentive regime, the flexibility of the fiscal system, the degree of sophistication of the financial sector, and the underlying political economy"(Hausmann and Rodrik 2002, p.17). In other words, to a large extent, police-makers are out there on their own. 


\section{References}

Abreu, Marcelo, 2004. “Implications of China's Emergence in the Global Economy for Latin America and the Caribbean Region. The case of Brazil. Background Paper Prepared for the Inter-American Development Bank Report on China." Washington, D.C.

Aghion, Phillippe and Peter Howitt, 1992. "A Model of Growth through Creative Destruction." National Bureau of Economic Research Working Paper 3223.

Ahearne, Alan G., John G. Fernald, Prakash Lougani and John W. Schindler, 2003. "China and Emerging Asia: Comrades or Competitors?" Federal Reserve Bank of Chicago Working Paper no 2003-27.

Antweiler, Werner and Daniel Trefler, 2002. "Increasing Returns and All That: A view from trade." NBER Working Paper 7941, October.

Blum, B. and Edward Leamer, 2004. 'Can FTAA Suspend the Law of gravity and Give Americas Higher Growth and Better Income Distributions'. in A. Estevadeordal, D. Rodrik, A. Taylor and A. Velasco (eds.), FTAA and Beyond: Prospects for Integration in the Américas, David Rockefeller Center for Latin American Studies, Harvard University Press.

Chami, Batista J. and J.P. Azevedo, 2002. NAFTA and the loss of U.S. market share by Brazil, 1992-2001. Cepal Review, 78:167-82.

Chenery, H. Sherman Robinson and Moshe Syrquin, 1986. Industrialization and Growth. A Comparative Study. Oxford University Press for the World Bank.

China Statistical Yearbook (CSY), 2003.

Claro, Sebastian, 2004. “Implications of China's Emergence in the Global Economy for Latin America and the Caribbean Region. The case of Chile. Background Paper Prepared for the Inter-American Development Bank Report on China." Washington, D.C.

De Ferranti, David, Guillermo Perry, Daniel Lederman and William Maloney, 2002. From Natural Resources to the Knowledge Economy. Trade and Job Quality. World Bank, Washington D.C.

Easterly, William and Ross Levine, 2003. "Tropics, germs, and crops: how endowments influence economic development." Journal of Monetary Economics 50, 3-39. 
Finger, J.M. and M. E. Krenin, 1979. "A Measure of "Export Similarity" and Its Possible Uses." The Economic Journal, Vol. 89, No 356, pp.905-912.

Grossman, Gene. and Elhanan. Helpman. 1994. “Technology and Trade." NBER Working Paper 4926, November.

Gylfason, Thorvaldur and Gylfi Zoega, 2002. "Inequality and Economic Growth: Do Natural Resources Matter?" Center for economic Studies \& ifo Institute for Economic Research Working paper No. 712 (5).

Gylfason, Thorvaldur, 2001. "Natural Resources and Economic Growth: What is the Connection." Center for economic Studies \& ifo Institute for Economic Research Working paper No. 530.

Hausman, Ricardo, 2003. "Venezuela's Growth Implosion: A Neoclassical Story?" in Dani Rodrik (ed.), In Search of Prosperity. Princeton University Press.

Hausmann, R. and Dani Rodrik, 2002. “Economic Development as SelfDiscovery. “ NBER Working Paper 8952, May.

Hu, Albert G.Z. Hu , Gary H. Jefferson, Guan Xiaojing and Qian Jinchang, 2003. "R\&D and Technology Transfer: Firm-Level Evidence from Chinese Industry. “William Davidson Institute working Paper no 582, June.

Inter-American Development Bank, 2001 Competitiveness: The Business of Growth. Washington: John Hopkins University Press for the Inter-American Development Bank.

Isham, Jonathan, Michael Woolcock, Lant Pritchett, and Gwen Busby, 2003. “The Varieties of Resource Experience: How Natural Resource Export Structures Affect the Political Economy of Economic Growth." Middlebury College Economics Discussion Paper No.03.08.

Jefferson, Gary H., Inderiit Singh, Xing Junling and Zhang Shouging, 1999 "Chinas Industrial Performance ': A Review of Recent Findings." In Jefferson, Gary $\mathrm{H}$ and Inderjit Singh (eds.) Enterprise Reform in China. Ownership, Transition and Performance. Oxford University Press for the World Bank.

Jefferson, Gary H., Thomas G. Rawski, Wang Li and Zheng Yuxin , 2000. "Ownership, Productivity Change, and Financial Performance in Chinese Industry." Journal of Comparative Economics 28.4, pp.786-813. 
Krueger, Anne O., 1979. The Developmental Role of the Foreign Sector and Aid. Studies in the Modernization of The Republic of Korea: 1945-1975. Harvard University Press, Cambridge, MA.

Kruger, Ann, 1984. "Comparative Advantage and Development Policy Twenty Years Later." In M. Syrquin, L. Taylor, and L. E. Westphal, eds. Economic Structure and Performance: Essays in Honor of Hollis B. Chenery. New York Academic.

Lall, S. (2000) "The technological structure and performance of developing country manufactured exports, 1985-98", Oxford Development Studies, Vol. 28, No. 3, 337-69.

Lall , Sanjaya and Manuel Albaladejo, 2003. "China's Competitive Performance: a threat to East Asian manufactured Exports?" World Development, Vol. 32, no.9, pp 1441-1466.

Lall, Sanjaya, Manuel Albaladejo and Mauricio Mesquita Moreira, 2004. "Latin America Industrial Competitiveness and the Challenges of Globalization." IDB-INTAL-ITD Occasional Paper No5. Washington, DC.

Lederman, Daniel and William F. Maloney, 2003. "Trade Structure and Growth." World Bank Policy Research Working Paper 3025, April.

Li, Kui-Wai (2003) “China's Capital and Productivity Measurement using Financial Resources" Economic Growth Center Discussion Paper No851, Yale University.

López Córdova, E and Moreira, Mauricio Mesquita, 2004. "Regional integration and productivity: the experiences of Brazil and Mexico." in A. Estevadeordal, D. Rodrik, A. Taylor and A. Velasco (eds.), FTAA and Beyond: Prospects for Integration in the Americas. David Rockefeller Center for Latin American Studies, Harvard University Press.

Lopez-Cordova, Ernesto, 2004. “Economic Integration and Manufacturing Performance in Mexico: Is Chinese Competition to Blame?" Background Paper Prepared for the Inter-American Development Bank Report on China. Washington, D.C.

Loyaza, Norman, P. Fajnzylber and C. Calderón, 2002. "Economic Growth in Latin America and The Caribbean. Stylized facts, explanations and forecasts." World Bank, Washington D.C., Processed.

Mckinsey Global Institute, 2003. “New Horizons: Multinational Investment in Developing Countries." San Francisco. 
Manzano, Osmel and Roberto Rigobon ,2001. "Resource Curse or Debt Overhang." NBER Working Paper 8390, July.

Muendler, Marc-Andreas, 2004. “Trade, Technology and Productivity: A Study of Brazilian Manufacturers, 1986-1998." CESifo Working Papers. No 1148

Murphy, Kevin M., Andrei Shleifer and Robert W. Vishny, 1989. "Industrialization and the Big Push." Journal of Political Economy, vol. 97. No 5. pp. 1003-1025.

National Bureau of Statistics of China (NBS-China). http://www.stats.gov.cn

Naughton, Barry, 2004. "China: Development Strategy and Policy Regime." A Background Paper Prepared for the Inter-American Development Bank Report on China. Washington, D.C.

Nolan, Peter and J. Zhang, 2002. "The Challenge of Globalization for Large Chinese Firms." World Development, vol.30 No.12, pp2089-2107.

Nordas, Hildelgunn Kyvik, 2004. The Global Textile and Clothing Industry post the Agreement on Textiles and Clothing. WTO working paper No5.

People's Daily on Line, 2004. http://english.people.com.cn, June 30.

Prebisch, R., 1950. "The Economic Development of Latin America and its Principal Problems. Lake Success, N.Y.: United Nations Department of Social Affairs.

Rowthorn, Robert and Ramana Ramaswamy, 1997. "Deindustrialization: Causes and Implications." IMF Working Paper 97/42.

Sachs, J., Warner, A., 1995. "Natural Resource Abundance and Economic Growth. “ National Bureau of Economic Research Working Paper 5398.

Sachs, J., Warner, A., 1997. "Fundamental sources of long-run growth." American Economic Review Papers and Proceedings 87, 184-188.

Stiglitz, Joseph, 2002. "Whither Reform? Towards a New Agenda for Latin America." Paper presented at the Economic Commission for Latin America and the Caribbean, in Santiago, Chile, on 26 August 2002.

Stijns, Jean-Philippe, 2003. "An Empirical Test of the Dutch Disease Hypothesis Using a Gravity Model of Trade. "Paper presented at the 2003 Congress of the EEA, Stockholm, July. 
Tybout, J.R. and M. Daniel Westbrook, 1995. "Trade Liberalization and The Dimensions of Efficiency Change in Mexican Manufacturing Industries." Journal of International Economics 39: 53-78.

UNCTAD, 2003. World Investment Report. Geneva.

UNIDO, 2002, Industrial Development Report, 2002/2003. United Nations, Geneva.

United States Trade Representative (USTR), 2003. Report to Congress on China's WTO Compliance. December. Washington D.C.

Wacziarg, R., Enrico Spolaore and Alberto Alesina, 2002. "Trade, Growth and Size of the Countries." Harvard University Working Paper 03-14.

Wang, Zijian and Jiegen Wei, 2004. "Structural Change, Capital's Contribution and Economic Efficiency: Sources of China's Economic Growth Between 1952-1988." Department of Economics, Gothenburg University. Mimeo.

World Trade Organization, 2003. Protocol on the Accession of China. Cambridge University Press.

Young, Alwyn, 2003. "Gold into Base Metals: Productivity Growth in the People's Republic of China during the Reform Period." Journal of Political Economy, 2003, vol. 111, no.6. 
Table A-1.Median Regression: Manufacturing Share of GDP (in log). Explanatory Variables (in log)

Real PPP Per capita income (RPPP)

1.71

$(0.3293)^{* * *}$

Square of RPPP

Capital stock per capita

$(0.0198)^{* \star *}$

0.0485

$-0.0354$

Labor Force

0.0773

Crop land per capita

$(0.0113)^{* * *}$

$-0.0664$

$(0.0222)^{\star * *}$

Pasture land per capita

0.0141

$-0.009$

Forest land per capita

0.0108

$-0.0113$

Share of pop. with some tertiary education

0.0715

$(0.0243)^{\star * *}$

0.0327

Share of pop. with some secondary education

Share of pop. with some primary education

0.1315

Share of pop. with no education

0.0072

$-0.0229$

$-0.0345$

Energy stock per capita

$(0.0107)^{* \star *}$

275

Observations

67

Countries

0.3647

Pseudo R2

Standard errors in parentheses

*** significant at $1 \%$

Controls included year dummies

Data on endowment from Antweiler and Trefler (2000). Data on Manufacturing Share from the WDI and data on per capita income from Penn World Tables 6.1 